\title{
DISTRIBUTION PATTERNS OF IBERIAN CARABIDAE (INSECTA, COLEOPTERA)
}

\author{
J. Serrano ${ }^{1}$, J. L. Lencina ${ }^{1}$ and A. Andújar ${ }^{2}$
}

\begin{abstract}
We have categorised the 1336 species and subspecies of the Iberian Peninsula according to the chorotype classification proposed by Vigna Taglianti et al. (1992), modified by the addition of new chorotypes. The Iberian Peninsula is noticeable among the different European and Circum-Mediterranean regions by the high proportion of endemic taxa (43.1\%). The old age and stability of the northern half, the extreme position of the Peninsula within the Eurasiatic continent, alpine tectonics and abundance of caves are among the factors that have probably contributed to the origin of a distinctive fauna. Taxa with a large distribution pattern are predominant at a regional scale; the proportion of endemic taxa increases to the North and in mountain regions; Mediterranean elements are more frequent in the South whereas European elements increase in the northern half. Adaptation to a Mediterranean climatic regime and dispersal are two of the factors causing these patterns. The Peninsula is poor in Afrotropical elements, probably because of the strong isolation derived from the Sahara Desert. The Balearic Islands have high proportions of widely distributed and Mediterranean taxa, what suggests a main role of dispersal in the colonisation of the archipelago. The proportion of endemic taxa in Mallorca $(7.8 \%)$ is intermediate between that of Sardinia and Sicily; in spite of a relatively long isolation, the Balearic Islands are small in size and moderately rich in caves, what explains that most endemic taxa are found in the lowlands.
\end{abstract}

Keywords: Carabidae, Iberian Peninsula, Balearic Islands, distribution, chorotypes.

\section{RESUMEN}

\section{Patrones de distribución de los Carabidae ibéricos (Insecta, Coleoptera)}

Se han categorizado las 1336 especies y subespecies de la fauna ibérica de Carabidae, usando los corotipos propuestos por Vigna Taglianti et al. (1992), los cuales se han completado con algunos otros adicionales. La Península Ibérica destaca entre las diversas regiones europeas y circunmediterráneas por la elevada proporción de elementos endémicos $(43,1 \%)$. La antigüedad y estabilidad de la mitad norte peninsular, el aislamiento de la región, los plegamientos alpinos y la abundancia de cuevas, son factores que probablemente han contribuido a su singularidad faunística. Los elementos de amplia distribución predominan a la escala regional; las proporciones de endemismos son mayores hacia el Norte y en las zonas de montaña; la de los elementos mediterráneos se incrementa hacia el Sur, al contrario de lo que ocurre con los elementos europeos. La adaptación al régimen climático mediterráneo y la dispersión son dos de los factores que probablemente causan estos patrones. La Península es pobre en elementos afrotropicales, posiblemente debido al aislamiento causado por la barrera natural del Sahara. Las Islas Baleares tienen altas proporciones de elementos de amplia distribución y mediterráneos, lo que sugiere el papel relevante de la dispersión en la colonización de las islas. La proporción de endemismos de Mallorca $(7,8 \%)$ es intermedia entre la de Cerdeña y Sicilia; a pesar de su aislamiento las Baleares son de tamaño pequeño y tienen un abundancia moderada de medios favorables para la especiación, como ocurre con las cuevas, lo que explica que la mayoría de los endemismos se encuentren en zonas abiertas de baja altitud.

Palabras clave: Carabidae, Península Ibérica, Islas Baleares, distribución, corotipos.

Departamento de Zoología, Facultad de Veterinaria, Universidad de Murcia. Aptdo. 4021. 30071 Murcia (Spain). jserrano@um.esy j11@um.es

Instituto No 4 de Hellín, Avda. de la Constitución, 21. 02400 Hellín (Albacete, Spain). andujar@inicia.es 


\section{Introduction}

The present distribution of species is usually the result of complex interactions between adaptation to particular conditions, power of dispersal and colonisation, history, and chance. The use of chorotypes for characterising in a single word such a complex sequence of events, is useful in terms of economy but may be more interesting for revealing a common process that influenced the distribution of whole floras and faunas, as it is the case of the biotic interchange that followed the connection between the Americas after the closure of the Panama Isthmus, 1,9 million years ago (Marshall, 1988), or the occurrence of vicariant events after the separation between the Iberian Peninsula and North Africa about 5.5 million years ago (López-Martínez, 1989; Rogl \& Steininger, 1983).

The development of categories for characterising the species distribution has not yet reached a wide consensus and hence these categories may vary significantly depending on the author consulted. Thus, the meaning of the category "West Palearctic" is not the same in the recent books of Hůrka (1996) and Turin (2000). This is also found in papers dealing with the Iberian carabid fauna (Novoa et al., 1989 and 1996 versus Andújar et al., 2000).

Italian researchers attained a valuable consensus on the categorisation of chorotypes (Vigna Taglianti et al., 1992), after a deep discussion that took into account the distribution patterns of different types of animals (most of them insects). We have selected the chorotypes put forward in that paper as a starting point for developing the geographic categorisation of the Iberian carabid fauna. The goals of this paper are to: 1) Present an updated catalogue of the Iberian carabid fauna categorised into chorotypes that follow the criteria postulated by Vigna Taglianti et al. (1992); 2) Make this catalogue accessible through Internet to anyone working with the geographic distribution of Iberian Carabidae; 3) Keep the catalogue actualised with the collaboration of researchers, by adding, deleting or correcting the categories of the chorotypes. This actualisation includes also changes concerning the taxa and their nomenclature, and the distribution data in the Iberian Peninsula and the Balearic Islands as well. This basic information may be used to build up more complex databases, to develop regional or local studies starting on a basic knowledge, etc.

\section{Methods}

SPECIES LIST

The list of species of the Iberian Peninsula and the Balearic Islands (Table 1) follows the ordination of the new catalogue of Iberian Carabidae (Serrano, 2003). It includes 1161 species. The need of describing the distribution of taxa in the different natural regions of the Iberian Peninsula (see below) justifies the consideration of subspecies for those polytypic species. Therefore, the total number of categorised taxa included in the analyses of the faunistic composition of the natural regions is 1336 species and subspecies. For each taxon of the list it is indicated the code corresponding to its chorotype.

\section{SOURCES OF DISTRIBUTION DATA}

The new catalogue of Iberian Carabidae (Serrano, 2003) includes detailed information for species with a restricted area (often endemic to mountains, caves, etc.), but only offers a general indication of the distribution of taxa which are widely distributed. For assessing the presence of each taxon in the natural regions of Iberia, we have made an exhaustive search of any paper having distributional information. This makes a long bibliographic list (more than 530 references) that will be also available in the Internet page of the Museo Nacional de Ciencias Naturales, or upon request to us. These data have been completed with the inclusion of our personal records not yet published. Data of authors have been reinterpreted according to the systematics used in the new catalogue, particularly those ones of old papers based on past nomenclatural criteria. The finding of old names is possible by searching them in the species list, as most used synonyms are also mentioned.

\section{CRITERIA FOR CATEGORISING THE CHOROTYPES}

The species with a large distribution range have been categorised according to the criteria put forward by Vigna Taglianti et al. (1992) (Table 1). Eight new chorotypes have been added to the list when the distribution pattern of species does not fit the initial list. These new categories are:

- Turano South Mediterranean. This distribution includes the Turanian region and the southern half of the Mediterranean basin, with a western limit in Andalusia and (or) southeast Spain. The distribution of Megacephala euphratica is an example of this pattern. Code number 1.14.

- The Alpine chorotype refers to orophilous species that occupy the Pyrenees (and sometimes the 
Table 1.- Chorotypes used in this work based on the criteria proposed by Vigna Taglianti et al. (1992).

Table 1.- Corotipos usados en el presente trabajo basados en los criterios propuestos por Vigna Taglianti et al. (1992).

\begin{tabular}{lll}
\hline Code & Acronym & Distribution range \\
\hline 0.01 & COSM & Cosmopolitan \\
1.01 & HOLA & Holarctic \\
1.02 & PALE & Palearctic \\
1.03 & WPAL & West-Palearctic \\
1.04 & ASER & Asiatic-European \\
1.05 & SIER & Sibirian-European \\
1.06 & CAEM & Centralasiatic-European-Mediterranean \\
1.07 & CAER & Centralasiatic-European \\
1.08 & CAME & Centralasiatic-Mediterranean \\
1.09 & TEUM & Turanian-European-Mediterranean \\
1.10 & TUER & Turanian-European \\
1.11 & TUME & Turanian-Mediterranean \\
1.12 & EUME & European-Mediterranean \\
1.14 & TSER & Turanian-South European \\
2.01 & EURP & European \\
2.03 & CEUR & Central-European \\
2.04 & SOER & South-European \\
2.05 & WEUR & West-European \\
2.07 & ALPI & Alpine \\
3.01 & MEDT & Mediterranean \\
3.02 & WMED & West-Mediterranean \\
3.04 & NAFR & North-African \\
3.05 & MESI & Mediterranean-Sindian \\
3.06 & ATLA & Atlantic Litoral \\
3.07 & NOME & North-Mediterranean Litoral \\
4.01 & AIME & Afrotropic-lndo-Mediterranean \\
4.02 & AFME & Afrotropic-Mediterranean \\
4.03 & INME & Indo-Mediterranean \\
5.04 & SASI & Saharian-Sindian \\
6.00 & ENDE & Endemic \\
6.01 & BERI & Betic-Riffian \\
6.02 & LION & Lioniguric \\
6.03 & IBMG & Ibero-Maghrebian \\
6.04 & CAPR & Catalonian Provencale \\
\hline & &
\end{tabular}

Cantabric Mountains too) and one or more of the following mountains: the Alps, the Central Massif, the Apennines, the Carpathian Mountains, etc. Nebria rufescens is a good example of this chorotype. In some cases, these species are also found up to Scandinavia and North America. Code number 2.07.

- Northern Mediterranean littoral. This category is applied to species of the northern Mediterranean seashore. Species of Southern Europe not restricted to the sea border and with a wide altitudinal range have been already classified into the 2.04 chorotype. Pogonus meridionalis and P. riparius have this geographic pattern. Code number 3.07.
- The Atlantic chorotype is applied to species inhabiting the littoral and sublittoral zones between Morocco and the English Channel. Aepopsis robinii and Cillenus lateralis are examples of this chorotype. Code number 3.06.

Taxa exclusive of the whole Peninsula (including the Pyrenees) or restricted to one or more of its natural regions are considered as the "endemic" chorotype. Vigna Taglianti et al. (1992) also considered subendemic taxa. In the case of the Iberian Peninsula these taxa should be broadly considered as Western Mediterranean elements, but their present distribution restricted to the Iberian Peninsula and either southern France or northern Morocco, is perhaps suggesting recent vicariant or dispersal events at a regional scale. Categories for these taxa are:

- Betic-Riffian species occupy the mountains of the south Iberian Peninsula and the Rif Mountains of northern Morocco. In some cases the distribution range includes the Sistema Central in Iberia or the northern part of the Atlas Mountains. Bembidion schmidti and Penetretus temporalis have this pattern. Code number 6.01.

- Lioniguric species are also orophilous taxa that are found in the mountain arch made up the Catalonian Chain and the Alps Maritimes between France and Italy. Occasionally the distribution range may extend southwards. Aptinus pyrenaeus is an example of this pattern. Code number 6.02.

- Iberian-Maghrebine elements are taxa occupying the southern half of Iberia and North Morocco, extending farther to North Algeria and Tunisia is some cases. The altitudinal range of taxa is large but most of them prefer the lowlands. Elaphrus lheritieri and Siagona dejeani are examples of this chorotype. Code number $\mathbf{6 . 0 3}$.

- Catalonian-Provencale elements are equivalent to lioniguric elements but always prefer the lowlands, and are therefore found between south France and the Mediterranean coast of Catalonia, sometimes extending their range farther into the Iberian Peninsula or along littoral and sublittoral regions towards the South. Poecilus laevigatus has this distribution pattern. Code number 6.04.

The complete list of chorotypes used in this work is indicated in the Table 1. We have omitted the chorotypes indicated by Vigna Taglianti et al. (1992) without representatives in the Iberian Peninsula. 
Table 2.- Total number of species of Carabidae and percentages of chorotypes (in brackets) recorded for the Iberian Peninsula, its natural regions and each of the Balearic Islands. Acronym of chorotypes as in table 1. IBP Iberian Peninsula, COS Southernmost Cone, PEN Penibetic Chains, ALM Almeria Plain, BET Betic Chains and River Guadalquivir Basin, ALG Algarve, SME South Meseta, MUR Murcia Plain, VAL Valencia Plain, POR littoral of Portugal, CEN Central Chains, SIB South Iberian Chain, EBR River Ebro Basin, NIB North Iberian Chain, NME North Meseta, GAL Galician-Douro region, LEO Mountains of Leon, CTB Cantabrian Mountains, BAC Basque Country, PYR Pyrenees, CAT Catalonia, IBZ Ibiza, MAL Mallorca, MEN Minorca.

\begin{tabular}{|c|c|c|c|c|c|c|c|c|c|c|c|c|c|c|c|c|}
\hline Code & Acronym & IBP & $\cos$ & PEN & ALM & BET & ALG & SME & MUR & VAL & POR & CEN & SIB & EBR & NIB & NME \\
\hline 0.01 & $\cos M$ & $3(0,3)$ & $2(0,6)$ & $1(0,3)$ & 0 & $2(0,5)$ & $3(1,6)$ & $3(0,7)$ & $2(0,8)$ & $1(0,6)$ & $3(1,2)$ & $1(0,3)$ & $1(0,3)$ & $1(0,5)$ & $2(0,7)$ & $1(0,3)$ \\
\hline 1.01 & HOLA & $8(0,7)$ & $1(0,3)$ & $2(0,6)$ & 0 & $3(0,7)$ & 0 & $5(1,1)$ & 0 & $1(0,6)$ & $3(1,2)$ & $5(1,3)$ & $4(1,3)$ & $3(1,4)$ & $6(2,0)$ & $5(1,6)$ \\
\hline 1.02 & PALE & $23(2,0)$ & $14(4,1)$ & $15(4,5)$ & $107,1)$ & $17(4,2)$ & $13(7,0)$ & $18(4,1)$ & $15(6,0)$ & $11(6,1)$ & $10(4,0)$ & $17(4,3)$ & $15(4,8)$ & $16(7,7)$ & $16(5,4)$ & $16(5,2)$ \\
\hline 1.03 & WPAL & $21(1,8)$ & $11(3,2)$ & $13(3,9)$ & $7(5,0)$ & $14(3,5)$ & $6(3,2)$ & $19(4,3)$ & $10(4,0)$ & $9(5,0)$ & $11(4,4)$ & $17(4,3)$ & $15(4,8)$ & $11(5,3)$ & $16(5,4)$ & $18(5,8)$ \\
\hline 1.04 & ASER & $29(2,5)$ & $2(0,6)$ & $2(0,6)$ & $1(0,7)$ & $7(1,7)$ & 0 & $9(2,0)$ & $3(1,2)$ & $1(0,6)$ & $2(0,8)$ & $13(3,3)$ & $11(3,5)$ & $7(3,4)$ & $13(4,4)$ & $14(4,5)$ \\
\hline 1.05 & SIER & $58(5,0)$ & $7(2,1)$ & $6(1,8)$ & $3(2,1)$ & $8(2,0)$ & $3(1,6)$ & $16(3,6)$ & $4(1,6)$ & $4(2,2)$ & $9(3,6)$ & $20(5,0)$ & $16(5,1)$ & $10(4,8)$ & $18(6,1)$ & $20(6,5)$ \\
\hline 1.06 & CAEM & $10(0,9)$ & $7(2,1)$ & $3(0,9)$ & $1(0,7)$ & $7(1,7)$ & $2(1,1)$ & $10(2,3)$ & $6(2,4)$ & $3(1,7)$ & $3(1,2)$ & $5(1,3)$ & $3(1,0)$ & $5(2,4)$ & $4(1,3)$ & $5(1,6)$ \\
\hline 1.07 & CAER & $19(1,6)$ & $1(0,3)$ & $1(0,3)$ & 0 & $6(1,5)$ & $3(1,6)$ & $6(1,4)$ & $3(1,2)$ & $3(1,7)$ & $5(2,0)$ & $9(2,3)$ & $8(2,6)$ & $6(2,9)$ & $10(3,4)$ & $4(1,3)$ \\
\hline 1.08 & CAME & $5(0,4)$ & $3(0,9)$ & $1(0,3)$ & $2(1,4)$ & $3(0,7)$ & $2(1,1)$ & $5(1,1)$ & $4(1,6)$ & $3(1,7)$ & $3(1,2)$ & $3(0,8)$ & $2(0,6)$ & $3(1,4)$ & $2(0,7)$ & $2(0,6)$ \\
\hline 1.09 & TEUM & $19(1,6)$ & $13(3,8)$ & $10(3,0)$ & $6(4,3)$ & $17(4,2)$ & $7(3,8)$ & $15(3,4)$ & $12(4,8)$ & $7(3,9)$ & $11(4,4)$ & $14(3,5)$ & $11(3,5)$ & $11(5,3)$ & $13(4,4)$ & $13(4,2)$ \\
\hline 1.10 & TUER & $20(1,7)$ & $6(1,8)$ & $2(0,6)$ & $1(0,7)$ & $9(2,2)$ & $1(0,5)$ & $13(2,9)$ & $3(1,2)$ & $5(2,8)$ & $6(2,4)$ & $8(2,0)$ & $11(3,5)$ & $5(2,4)$ & $6(2,0)$ & $9(2,9)$ \\
\hline 1.11 & TUME & $24(2,1)$ & $10(2,9)$ & $8(2,4)$ & $7(5,0)$ & $17(4,2)$ & $6(3,2)$ & $19(4,3)$ & $12(4,8)$ & $5(2,8)$ & $7(2,8)$ & $10(2,5)$ & $5(1,6)$ & $7(3,4)$ & $4(1,3)$ & $6(1,9)$ \\
\hline 1.12 & EUME & $27(2,3)$ & $19(5,6)$ & $17(5,0)$ & $8(5,7)$ & $23(5,7)$ & $11(5,9)$ & $25(5,7)$ & $18(7,2)$ & $18(10,1)$ & $21(8,4)$ & $22(5,5)$ & $19(6,1)$ & $16(7,7)$ & $18(6,1)$ & $17(5,5)$ \\
\hline 1.14 & TSER & $11(0,9)$ & $3(0,9)$ & $5(1,5)$ & $4(2,9)$ & $4(1,0)$ & $2(1,1)$ & $7(1,6)$ & $5(2,0)$ & $5(2,8)$ & $2(0,8)$ & $2(0,5)$ & $5(1,6)$ & $4(1,9)$ & $3(1,0)$ & $4(1,3)$ \\
\hline 2.01 & EURP & $63(5,4)$ & $9(2,6)$ & $7(2,1)$ & $2(1,4)$ & $16(4,0)$ & $7(3,8)$ & $20(4,5)$ & $8(3,2)$ & $7(3,9)$ & $12(4,8)$ & $25(6,3)$ & $22(7,1)$ & $11(5,3)$ & $25(8,4)$ & $24(7,8)$ \\
\hline 2.03 & CEUR & $3(0,2)$ & 0 & 0 & 0 & 0 & 0 & 0 & 0 & 0 & 0 & 0 & 0 & 0 & 0 & 0 \\
\hline 2.04 & SOER & $25(2,2)$ & $7(2,1)$ & $7(2,1)$ & $4(2,9)$ & $11(2,7)$ & $4(2,2)$ & $12(2,7)$ & $7(2,4)$ & $5(2,8)$ & $5(2,0)$ & $12(3,0)$ & $14(4,5)$ & $10(4,8)$ & $13(4,4)$ & $9(2,9)$ \\
\hline 2.05 & WEUR & $21(1,8)$ & $3(0,9)$ & $5(1,5)$ & $1(0,7)$ & $9(2,2)$ & $1(0,5)$ & $3(0,7)$ & $3(1,2)$ & $5(2,8)$ & $4(1,6)$ & $11(2,8)$ & $10(3,2)$ & $4(1,9)$ & $8(2,7)$ & $9(2,9)$ \\
\hline 2.07 & ALPI & $15(1,3)$ & 0 & $2(0,6)$ & 0 & 0 & 0 & $1(0,2)$ & 0 & $1(0,6)$ & 0 & $3(0,8)$ & $2(0,6)$ & 0 & $3(1,0)$ & $2(0,6)$ \\
\hline 3.01 & MEDT & $64(5,5)$ & $48(14,1)$ & $32(9,5)$ & $24(17,1)$ & $42(10,4)$ & $28(15,1)$ & $50(11,3)$ & $39(15,6)$ & $27(15,1)$ & $26(10,4)$ & $26(6,5)$ & $20(6,4)$ & $21(10,1)$ & $18(6,1)$ & $24(7,8)$ \\
\hline 3.02 & WMED & $96(8,1)$ & $70(20,6)$ & $63(18,7)$ & $21(15,0)$ & $66(16,4)$ & $31(16,7)$ & $63(14,3)$ & $43(17,2)$ & $32(17,9)$ & $38(15,1)$ & $40(10,1)$ & $41(13,1)$ & $25(12,0)$ & $24(8,1)$ & $38(12,3)$ \\
\hline 3.04 & NAFR & $8(0,7)$ & $6(1,8)$ & $1(0,3)$ & $1(0,7)$ & $4(1,0)$ & $4(2,2)$ & $4(0,9)$ & $6(2,4)$ & $3(1,7)$ & $1(0,4)$ & 0 & $1(0,3)$ & $2(1,0)$ & 0 & $1(0,3)$ \\
\hline 3.05 & MESI & $1(0,1)$ & 0 & $1(0,3)$ & $1(0,7)$ & 0 & 0 & $1(0,2)$ & $1(0,4)$ & $1(0,6)$ & 0 & 0 & $1(0,3)$ & $1(0,5)$ & 0 & 0 \\
\hline 3.06 & ATLA & $5(0,4)$ & $2(0,6)$ & $1(0,3)$ & 0 & 0 & $1(0,5)$ & $1(0,2)$ & 0 & 0 & $3(1,2)$ & 0 & 0 & 0 & 0 & $1(0,3)$ \\
\hline 3.07 & NOME & $4(0,3)$ & $2(0,6)$ & $2(0,6)$ & $2(1,4)$ & $1(0,2)$ & $2(1,1)$ & $2(0,5)$ & $3(1,2)$ & $3(1,7)$ & 0 & 0 & 0 & 0 & 0 & $1(0,3)$ \\
\hline 4.01 & AIME & $1(0,1)$ & $1(0,3)$ & $1(0,3)$ & $1(0,7)$ & $1(0,2)$ & $1(0,5)$ & $1(0,2)$ & $1(0,4)$ & $1(0,6)$ & 0 & 0 & $1(0,3)$ & 0 & 0 & 0 \\
\hline 4.02 & AFME & $10(0,9)$ & $8(2,4)$ & $5(1,5)$ & $3(2,1)$ & $4(1,0)$ & $4(2,2)$ & $6(1,4)$ & $1(0,4)$ & $3(1,7)$ & $3(1,2)$ & $2(0,5)$ & $3(1,0)$ & $3(1,4)$ & $2(0,7)$ & $1(0,3)$ \\
\hline 4.03 & INME & $1(0,1)$ & $1(0,3)$ & 0 & 0 & 0 & $1(0,5)$ & $1(0,2)$ & $1(0,4)$ & 0 & 0 & 0 & 0 & 0 & 0 & 0 \\
\hline 5.04 & SASI & $3(0,3)$ & $1(0,3)$ & $2(0,6)$ & $1(0,7)$ & $1(0,2)$ & $1(0,5)$ & $1(0,2)$ & $1(0,4)$ & $1(0,6)$ & 0 & 0 & $1(0,3)$ & $1(0,5)$ & 0 & 0 \\
\hline 6.00 & ENDE & $500(43,1)$ & $41(12,1)$ & $90(26,7)$ & $19(13,6)$ & $76(18,9)$ & $29(15,6)$ & $78(17,7)$ & $18(7,2)$ & $11(6,1)$ & $49(19,5)$ & $115(28,9)$ & $55(17,6)$ & $18(8,7)$ & $67(22,6)$ & $54(17,5)$ \\
\hline 6.01 & BERI & $6(0,5)$ & $2(0,6)$ & $5(1,5)$ & 0 & $4(1,0)$ & 0 & $2(0,5)$ & 0 & 0 & 0 & $2(0,5)$ & $2(0,6)$ & 0 & 0 & 0 \\
\hline 6.02 & LION & $3(0,3)$ & 0 & $1(0,3)$ & 0 & $2(0,5)$ & 0 & $1(0,2)$ & $1(0,4)$ & 0 & 0 & 0 & $2(0,6)$ & 0 & 0 & 0 \\
\hline 6.03 & IBMG & $51(4,4)$ & $40(11,8)$ & $21(6,2)$ & $9(6,4)$ & $27(6,7)$ & $13(7,0)$ & $23(5,2)$ & $14(5,6)$ & $2(1,1)$ & $14(5,6)$ & $15(3,8)$ & $8(2,6)$ & $4(1,9)$ & $3(1,0)$ & $10(3,2)$ \\
\hline 6.04 & CAPR & $7(0,6)$ & 0 & $1(0,3)$ & $1(0,7)$ & $2(0,5)$ & 0 & $1(0,2)$ & $2(0,8)$ & $1(0,6)$ & 0 & $1(0,3)$ & $3(1,0)$ & $3(1,4)$ & $3(1,0)$ & $1(0,3)$ \\
\hline & total & 1161 & 340 & 337 & 140 & 403 & 186 & 441 & 250 & 179 & 251 & 398 & 312 & 208 & 297 & 309 \\
\hline
\end{tabular}

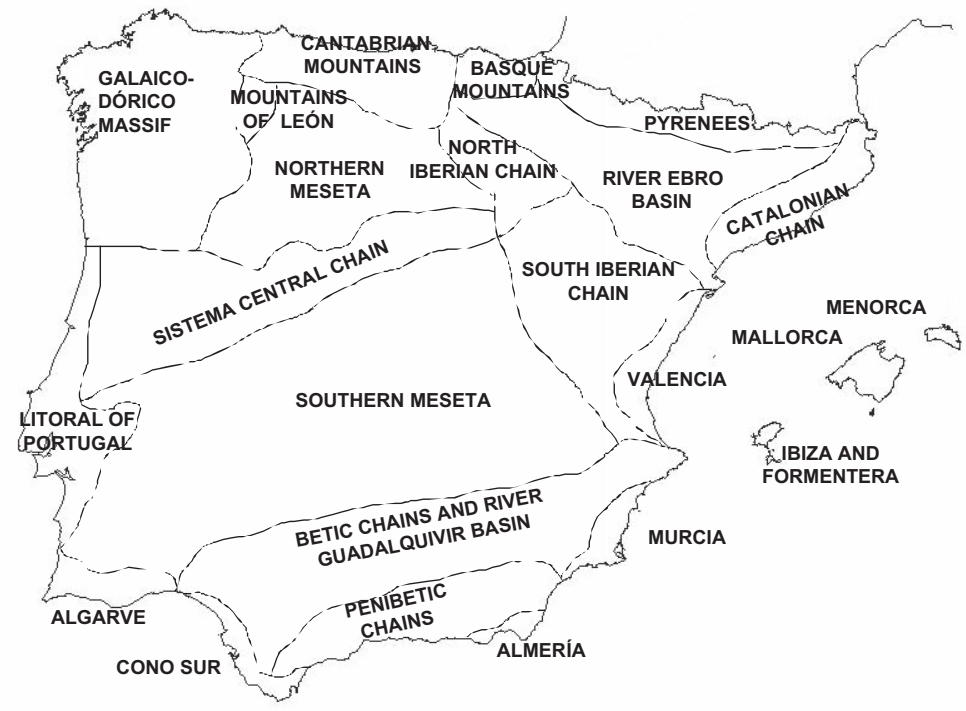

Fig. 1.- Map of the natural regions of the Iberian Peninsula and the Balearic Islands considered in this paper.

Fig. 1.- Mapa de las regiones naturales de la Península Ibérica e Islas Baleares utilizadas en este estudio. 
Tabla 2.- Número total de especies de Carabidae y porcentajes de corotipos (entre paréntesis) encontradas en la Península Ibérica, sus regiones naturales y las Islas Baleares. Acrónimos de los corotipos igual que en la Tabla 1. IBP Península Ibérica, COS Cono Sur, PEN Cadenas Penibéticas, ALM Planicie de Almería, BET Cadenas Béticas y cuenca del río Guadalquivir, ALG Algarve, SME Meseta Sur, MUR Planicie de Murcia, VAL Planicie de Valencia, POR litoral de Portugal, CEN Sistema Central, SIB Cadena Sudibérica, EBR Cuenca del Ebro, NIB Cadena Noribérica, NME Meseta Norte, GAL Región Galaico-Dórica, LEO Montes de León, CTB Cordillera Cantábrica, BAC País Vasco, PYR Pirineos, CAT Cataluña, IBZ Ibiza, MAL Mallorca, MEN Menorca.

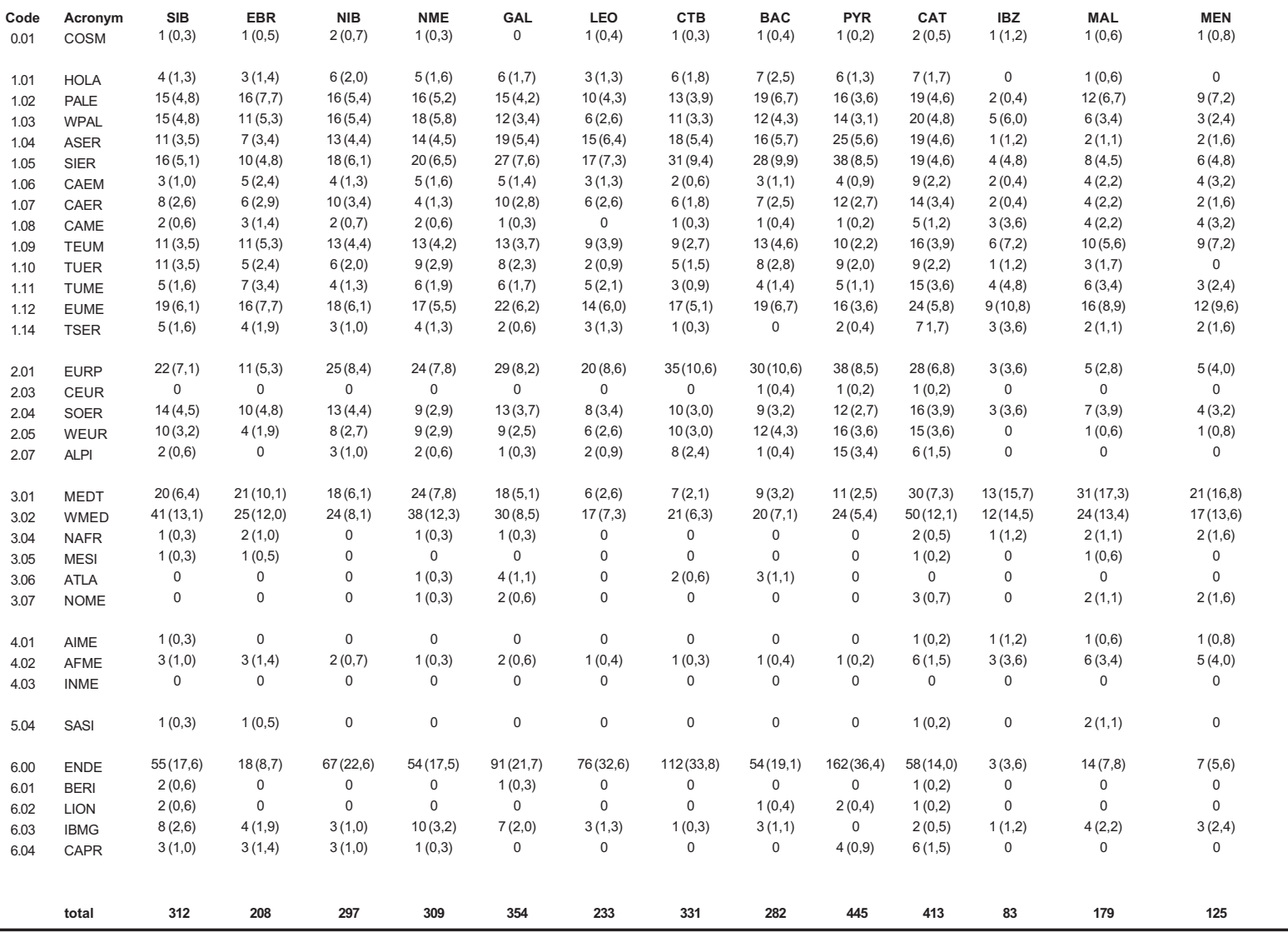

The natural Regions of the Iberian Peninsula AND THE BALEARIC ISLANDS

In order to analyse the geographic patterns at a regional scale the Iberian Peninsula has been divided into 22 natural regions, most of which were proposed by Jeanne in his catalogues of Iberian Carabidae (Jeanne, 1965-1978; Jeanne \& Zaballos, 1986; Zaballos \& Jeanne, 1994). To these regions it is added the three Balearic Islands (Fig. 1). Natural barriers and climatic conditions are the main factors that characterise the peninsular regions, but such division is only tentative and should be probably corrected when detailed faunistic analyses are carried out. We have added the Algarve as a distinct region, and have also differentiated the Penibetic from the Betic Mountains. The Sistema Central is considered as a unit (following Jeanne's ideas) but perhaps should be better divided into an East group (from the NE extreme to Guadarrrama mountains), a Central group including the sierras of Gredos, Béjar and Gata, and a western group including the Sierra de la Estrela in Portugal. Localities of species records situated in the border of these natural regions have been usually assigned to only one of them, based on altitude and predominant vegetation.

\section{Results}

The chorotype of all species and subspecies of Iberian Carabidae is indicated in the Appendix. A full version of this Appendix that includes the pre- 
Table 3.- Supraspecific taxa of Iberian carabid beetles with a high percentage of endemic species. Only taxa including 10 species or more are listed.

Tabla 3.- Taxones supraespecíficos de Carabidae ibéricos con un porcentaje elevado de endemismos. Sólo figuran aquellos que tienen 10 o más especies.

\begin{tabular}{llc}
\hline Tribe & Subtribe or genus & ratio endemic /total no. species, and total no. of species of the taxon \\
\hline Carabini & Carabus & $79.3 \%, 29$ species \\
Nebriini & Leistus & $56.3 \%, 16$ species \\
Nebriini & Nebria & $63.2 \%, 19$ species \\
Trechini & the whole tribe & $91.8 \%, 97$ species \\
Bembidiini & Anillina & $100 \%, 82$ species \\
Pterostichini & Molopina & $93.3 \%, 15$ species \\
Pterostichini & Cryobius & $94.1 \%, 17$ species \\
Pterostichini & Pterostichus & $44.4 \%, 27$ species \\
Zabrini & Zabrus & $93.3 \%, 30$ species \\
Sphodrini & Platyderus & $95.7 \%, 46$ species \\
Sphodrini & Calathus & $60.9 \%, 23$ species \\
Sphodrini & Laemostenus & $81.3 \%, 16$ species \\
Lebiini & Trymosternus & $100 \%, 10$ species \\
Lebiini & Cymindis & $46.2 \%, 13$ species \\
Brachinini & Brachinus & $45.5 \%, 22$ species \\
\hline
\end{tabular}

sence of each taxon in the natural regions of the Iberian Peninsula will be available in an Internet page developed by the Museo Nacional de Ciencias Naturales (Madrid). Table 2 is directly derived from that complete Appendix. The number of taxa and percentages for the Iberian Peninsula and Balearic Islands as a whole, is referred to 1161 species (subspecies are not considered). However, and for the reasons indicated above, we have considered also the subespecies level (1336 taxa) to determine the faunistic composition of the natural regions of Iberia.

The Iberian Peninsula AND the BaLEaric Islands

Endemic taxa make up the most frequent chorotype of the Iberian Carabidae (500 species, $43,1 \%$ ). If subendemic chorotypes represented by 67 species $(5.8 \%)$ are added to the endemic taxa the percentage increases to $48.9 \%$.

Chorotypes corresponding to large distributional ranges (i.e., those with code numbers 0 and 1) are found in 277 species (23.9\%), whereas Mediterranean chorotypes (code number 2) are third in importance as they correspond to 176 species $(15.2 \%)$.

The endemic taxa are not randomly distributed within all tribes found in the Peninsula, but concentrated in particular supraspecific groups (Table 3). Orophiles and endogeous species make up the bulk of the endemic species, but some of them have a present distribution range limited to lowlands, as it happens in the genera Broscus, Percus, Poecilus, and Platyderus. The endemic taxa represent in some cases lineages exclusive of the Peninsula (Dalyat, Apoduvalius, Henrotius, Galiciotyphlotes, Ildobates, etc.), but most frequently are lineages living in a larger area with a more or less pronounced rate of speciation in Iberia. Some particular species are perhaps the Iberian counterpart of European or North African species (Harpalus wagneri, Calathus granatensis). The Balearic Islands have a low number of endemic species, most of which are cave dwellers, but there are also endemic species and subspecies inhabiting the lowlands (genera Cicindela, Orthomus, Platyderus).

The natural Regions of the Iberian Peninsula

The number of species and subspecies varies notably between natural regions of the Iberian Peninsula (Table 2). Lowest species richness is found in the Balearic Islands, whereas the Pyrenees, the South Meseta, Catalonia, the Betic Region and the Sistema Central, are the regions with the highest numbers of recorded species. Both natural and sampling factors seem to account for these results.

In most regions, the species with a large distribution range (distribution codes $0+1$ ) predomina- 
te, with percentages between $40-50 \%$. These chorotypes are more frequent in the northern half of the Peninsula and the Balearic Islands. European chorotypes (code number 2) are also more frequent in the North, always more than $10 \%$. In the South and the islands their frequency decreases below $10 \%$.

Mediterranean chorotypes (code number 3) have higher frequencies in the South, with percentages always higher than $25 \%$, whereas in the North their frequency decreases to $20 \%$ or less. In the Balearic Islands they make the second main group of chorotypes (more than 30\%).

Endemic taxa show the highest frequencies in the mountains: Pyrenees (36.4\%), Cantabrian Mountains (33.8\%), Mountains of León (32.6\%), the Central Chains (28.9\%) and Penibetic Mountains (26.7). This chorotype is found in low percentages in the islands, the coastal Mediterranean lowlands (Almería, Murcia, Valencia), and the Ebro Basin. Of the subendemic chorotypes only the ibero-maghrebine category makes up a significant percentage in the southern half of the Peninsula, as its frequency decreases in a SW-NE direction becoming lower than 5\% towards the Central Chains and NE Mediterranean regions (Valencia and Catalonia).

\section{Discussion}

Distribution PATterns In THE IBERIAN PENINSUla

The high proportion of endemic taxa is the most remarkable pattern of the Peninsula. This high percentage is also found in Anatolia (Casale \& Vigna Taglianti, 1999: 41.1\% of 1086 species) whereas in the Italian Peninsula is somewhat lower, about 30\% (of about 1350 species; Vigna Taglianti \& Casale, pers. com.). Other Mediterranean areas as Bulgaria have much lower proportions of endemic species, about $10 \%$ (total no. of species 741 ), according to the data indicated by Guéorguiev \& Guéorguiev (1995). If subendemic taxa are added the proportion of taxa almost exclusive of the Peninsula is close to $50 \%$.

These results agree with the hypothesis put forward by Oosterbroek \& Arntzen (1992), who stated that the Iberian Peninsula has been a major centre for the origin of the Mediterranean biota since the Oligocene period. The northern half of the Peninsula (except for the river Ebro Basin) corresponds to the emerged lands since the Palaeozoic period, and thus it is not surprising that includes regions (Galicia, Cantabrian Mountains, Northern Meseta, Pyrenees, etc.) with the higher proportions of endemic elements. The southern half of the Peninsula has a recent development since the Upper Miocene (10 MY), when the western microplates between Europe and Africa became incorporated to the Iberian Meseta (Rogl \& Steininger, 1983). Thus, age seems to be related to the lower amount of endemic elements in the Southern Meseta, the Betic and Penibetic Mountains, or the coastal regions (littoral of Portugal, Valencia, Murcia, etc.). The recent finding of Dalyat mirabilis in a cave of Almería (SE Spain), is demonstrative of the survival of an interesting paleoendemism in a stable and protected refugee. This species belongs to the tribe Promecognathini, which extant representatives are found in South Africa and North America.

In addition to age, other factors have probably influenced the high number of Iberian endemics, as are alpine tectonics and cave speciation. Mountain regions are very rich in endemic taxa. Active allopatric speciation has been favoured by the particular conditions of geographic isolation sheltered by the transversal orientation of most Iberian chains, particularly during the alternation of cold and warm periods of the late Cenozoic. The high altitudes of these chains also favours the formation of new species adapted to the different biotic and abiotic conditions that can be found from the lowlands to the 2000-3300 m range. In particular, the Pyrenees not only have favoured the formation of a rich endemic fauna but have also acted as a barrier for the dispersal of European elements into the Peninsula, thus increasing the isolation derived from its westernmost position into the Eurasiatic plate. The other transversal chains are not completely isolated due to the particular orientation of the Sistema Ibérico, which connects the northern chains with the Sistema Central and the NE Betic chains to the South. This fact explains the occurrence of endemic species and subspecies, which have a European origin in the Sistema Central, Sierra Nevada and the Sistema Ibérico as well. Conversely, some Betic or ibero-maghrebine taxa have possibly reached northern parts of Iberian using this pathway (Andújar et al., 2000). Another effect of the orientation and connections of Iberian mountains is the formation of species rings that occupy two or more massifs, as it happens in genera like Nebria, Calathus and Zabrus (Ortuño, 2002).

As expected, the influence of European lineages is better appreciated in the North, where taxa such as Carabus, Leistus, Nebria, Cryobius, Pterostichus, Steropus, etc., have originated many endemisms. On the contrary, Mediterranean and subtropical lineages are well represented in the South, as it happens with 
the genera Styracoderus, Orthomus, Zabrus, Platyderus, Calathus, Laemostenus, Parophonus, Trymosternus and Brachinus among others.

Taxa endemic to caves have speciated in most Iberian chains due the occurrence of many carbonate soils, except for the Galician-Douro region, the Sistema Central and Sierra Nevada, in which granitic soils are predominant. Some of the cave-dwellers taxa probably have an ancient origin, i.e., they are paleoendemisms. The northern half of the Iberian Peninsula has old massifs connected to the Eurasiatic plate since the separation of Laurasia and Gondwana, that allowed for the origin of lineages exclusive to the Peninsula, as are Iberodytes, Aphoenops, Apoduvalius, Geotrechus, Hydraphaenops, Hydrotrechus, Iberotrechus, Hypotyphlus, Microtyphlus, Speleotyphlus, Troglorites, Anchomenidius, and Galiciotyphlotes.

The southern half has some cave endemics that are probably of recent origin (as discussed below), as it happens with the pterostichine genus Tinautius. Other species may represent much older lineages, which have survived the extensive changes that happened since the Oligocene. In addition to Dalyat mirabilis, there are some other paleoendemisms such as Ildobates neboti (Zuphiini or Galeritini).

A second group of endemic geophiles is made up by species of the genera Typhlocharis, Geocharis, Oscadytes, Microtyphlus, etc. (and perhaps Zariquieya) inhabiting the soil at a moderate depth, that can be collected under large stones after a rainy season. Ortuño has rightly showed (2002) that this "superficial underground environment" (Juberthie et al., 1980) has a particular and very rich fauna, which has become well known in the last decade.

The endemic taxa are concentrated in particular lineages, as shown by the results of Table 2 . Although most of these lineages are not exclusive of the Iberian Peninsula, this region shows a distinctive feature because most of the species are true endemisms not shared with other European regions. Penev et al. (2003) already pointed out this distinctness of the Iberian Peninsula in the case of the genus Carabus, as 23 out of the 29 species of this genus are exclusive of Iberia. This is more evident in the case of the genera Trechus, Cryobius, Zabrus, Platyderus, Laemostenus and Trymosternus. These findings agree with the hypothesis that the Iberian Peninsula has been a major centre of speciation for Mesozoic and early Cenozoic carabid lineages existing in the western side of the Eurasiatic plate.

The other groups of chorotypes are (in a decreasing proportion) that one representing taxa with large distribution areas (codes $0+1,23.9 \%$ ), the
Mediterranean (code number 3, 15.2\%), and the Europeans $(10.9 \%)$. Their patterns are best considered by analysing the natural regions of the Peninsula (see below). The influence of Afrotropical (code number 4) and Saharan (code number 5) chorotypes in the Iberian Peninsula is very low, and only the afro-Mediterranean taxa (10 species) are relatively well represented. This finding suggests that the Peninsula has a typical Palearctic fauna with a poor influence from the Ethiopic and the Oriental regions.

DISTRIBUTION PATTERNS SHOWN BY THE NATURAL REGIONS OF IBERIA AND THE BALEARIC ISLANDS

A first inspection of the chorotype composition of each region shows that the species with a large distributional area, i.e., those with code numbers starting with 0 and 1 , make up the highest percentage in the northern half of the Peninsula, and are only slightly overcome in some of the southern regions by the Mediterranean chorotypes (code number 3 ). This is a clear effect of a change in geographic scale in comparison with the whole Peninsula, as widely distributed taxa are shared by most Iberian regions whereas endemic or European taxa are more restricted to particular regions.

Mediterranean chorotypes show the highest percentages in the southern half of Iberia and the Balearic Islands. The northern Meseta and the Ebro Basin are also rich in these chorotypes, a fact that suggests that they are better adapted to the environmental conditions associated to the Mediterranean climate. Conversely, the European chorotypes (code number 2) are more frequent in the northern regions. This finding is probably due to both dispersal and adaptation to local conditions.

The percentage of endemic elements is clearly higher in the mountainous areas of the northern half, for the reasons discussed above. In the South, they are better represented in the Penibetic and Betic regions, due to the development of altitudinal gradients and the abundance of cave environments. When subendemic taxa are taken into consideration (mostly the ibero-maghrebine elements), the percentages increase notably in most southern regions, a fact that is probably related to an active faunal interchange between South Iberia and North Africa.

The patterns shown by the regions may change in the future because not all of them have been equally sampled. For example, the Cono Sur is a small area between the provinces of Cadiz and Malaga, which has been sampled by many investigators since the last 40 years, what explains the high number of recorded species. Catalonia, the Pyrenees, the 
Basque country, the Galician-Douro region, the Sistema Central and Murcia are among the regions better sampled. Almería, the Algarve, the Penibetic and Betic regions, both Mesetas and the Mountains of Leon are not yet sufficiently known. Andújar et al. (2000) already showed that the Penibetic region and the South Iberian chains were not probably adequately sampled, after estimating the expected number of species for some mountainous areas of Iberia with the Mac Arthur \& Wilson's (1967) formula. The sampling effect is not only appreciated in that the species number is lower than expected for a given area, but also in that common or widely distributed species tend to be more easily recorded.

The Balearic Islands show a higher percentage of chorotypes with higher dispersal ability, that is, those ones with code number 0 and 1 . Mediterranean elements are only one third, a fact that suggest that dispersal instead adaptation to local conditions, has been the main factor for explaining the colonisation of the islands. The number of taxa exclusive to the islands is low, only 13 in Mallorca, 7 in Minorca and 3 in Ibiza. Most of them are lowland species, as cave dwellers are four in Mallorca and one in Minorca. Mallorca is probably the better-sampled island, whereas Ibiza has possibly a richer fauna not yet well known. The results of Mallorca are relatively similar to those found in Sardinia (Casale \& Vigna Taglianti, 1995). In this last island there are 349 carabid species, of which $53(12.3 \%)$ are endemic elements (7.8\% in Mallorca), a third $(36.7 \%)$ is due to Mediterranean chorotypes and a slightly higher percentage $(37.0 \%)$ is due to chorotypes denoting a wider distribution. It is probably that the high mountains of Sardinia and its well-developed system of caves offer many suitable places for the formation of endemic species. Also, the difference in size (Mallorca has $3640 \mathrm{~km}^{2}$ whereas Sardinia has $24089 \mathrm{~km}^{2}$ ) is probably influencing the amount of endemic taxa. In Sicily the Mediterranean elements predominate $(45.2 \%, 178$ species of a total of 394: Vigna Taglianti et al., 2002), whereas the percentage of species with a wider distribution pattern decreases to $29.7 \%$. The percentage of endemic elements is low (4\%). Vigna Taglianti et al. (2002) postulated that Pleistocene glaciations forced southwards the most termophilous species of the Apennine Peninsula, thus increasing the number of species better adapted to Mediterranean environments. The low number of endemisms is perhaps due to the lesser isolation of Sicily that has acted as a bridge between the Italian Peninsula and North Africa.

\section{ACKNOWLEDGEMENTS}

This work has been partially supported by the project "Fauna Ibérica", of the D.G.I.C.Y.T, PB95-0235. Many colleagues generously sent papers or personal records on the distribution of Iberian Carabidae: Emilio Carabajal, Ana Cárdenas, Achille Casale, Oleguer Escolà, José García Carrillo, Carles Hernando, Bernd Jaeger, Claude Jeanne, Boris M. Katayev, Vicente M. Ortuño, Miquel Palmer, Javier Pérez Valcárcel, Juan Pérez Zaballos, Ildefonso Ruiz Tapiador, José María Salgado, Ricardo Sciaky, Joachim Schmidt, Artur R. M. Serrano, Marcos Toribio, Augusto Vigna Taglianti, Eduard Vives, David Wrase and Alexandr Zamotailov. We are particularly indebted to Pepe Fernández (Fauna Ibérica project) for the search for new papers and records in the library of the Museo Nacional de Ciencias Naturales (CSIC, Madrid).

Carlos Ruiz, Carmelo Andújar and Juan Antonio Carvajal helped with calculations and ordering of data and literature.

\section{References}

Only papers cited in the text are mentioned here. Papers including distribution data of Iberian Carabidae within the 23 natural regions herewith considered will be available in an Internet page developed by http://www.mncn.csic.es/.

Andújar, A., Lencina, J. L., Ruano, L. \& Serrano, J., 2000. Los Caraboidea de las sierras suroccidentales de la provincia de Albacete. Instituto de Estudios Albacetenses "Don Juan Manuel". Albacete. 134 pp.

Casale, A. \& Vigna Taglianti, A., 1995. Coleotteri Carabidi di Sardegna e delle piccole isole circumsarde, e loro significato biogeografico (Coleoptera, Carabidae). Biogeographia, 18: 391-427.

Casale, A. \& Vigna Taglianti, A., 1999. Caraboid beetles (excl. Cicindelidae) of Anatolia and their biogeographical significance (Coleoptera, Caraboidea). Biogeographia, 20: 277-406.

Guéorguiev, V. B. \& GuÉorguiev, B. V., 1995. Catalogue of the ground beetles of Bulgaria (Coleoptera: Carabidae). Pensoft Publ. Sofia. 279 pp.

HŮRKA, K., 1996. Carabidae of the Czech and Slovak Republics. Kabourek. Zin. 565 pp.

Jeanne, C., 1965. Carabiques de la Péninsule Ibérique (2ème note). Actes de la Société linnéenne de Bordeaux, (Sér. A 10), 102(10): 1-34.

Jeanne, C., 1966. Carabiques de la Péninsule Ibérique (3ème note). Actes de la Société linnéenne de Bordeaux, (Sér. A, 7), 103 (7): 3-18.

Jeanne, C., 1967. Carabiques de la Péninsule Ibérique (4ème note). Actes de la Société linnéenne de Bordeaux, (Sér. A 3), 104(3): 1-24.

Jeanne, C., 1967. Carabiques de la Péninsule Ibérique (5ème note). Actes de la Société linnéenne de Bordeaux, , (Sér. A 10), 104(10): 1-22. 
Jeanne, C., 1967. Carabiques de la Péninsule Ibérique (6ème note). Actes de la Société linnéenne de Bordeaux, (Sér. A 13), 104(13): 1-19.

Jeanne, C., 1968. Carabiques de la Péninsule Iberique (7ème note). Actes de la Société linnéenne de Bordeaux, (Sér. A 1), 105(1): 1-25

Jeanne, C., 1968. Carabiques de la Péninsule lberique (8ème note). Actes de la Société linnéenne de Bordeaux, (Sér. A 6), 105(6): 1-40.

Jeanne, C., 1968. Carabiques de la Péninsule Ibérique (9ème note). Actes de la Société linnéenne de Bordeaux, (Sér. A 8), 105(8): 1-22.

Jeanne, C., 1969. Carabiques de la Péninsule Ibérique (lére note). Archivos del Instituto de Aclimatación, 14: 101-124.

Jeanne, C., 1971. Carabiques de la Péninsule Ibérique (10ème note). Bulletin de la Société linnéenne de Bordeaux, 1(2): 5-18.

Jeanne, C., 1971. Carabiques de la Péninsule Ibérique (11ème note). Bulletin de la Société linnéenne de Bordeaux, 1(9): 87-96.

Jeanne, C., 1971. Carabiques de la Péninsule Ibérique (12ème note). Bulletin de la Société linnéenne de Bordeaux, 1(9): 203-220.

Jeanne, C., 1972. Carabiques de la Péninsule Ibérique (13ème note). Bulletin de la Société linnéenne de Bordeaux, 2(2): 27-42.

Jeanne, C., 1972. Carabiques de la Péninsule Ibérique (14ème note). Bulletin de la Société linnéenne de Bordeaux, 2(5): 99-116.

Jeanne, C., 1973. Carabiques de la Péninsule Ibérique (ler suplément). Bulletin de la Société linnéenne de Bordeaux, 3(1): 3-20.

Jeanne, C., 1976. Carabiques de la Péninsule Ibérique (2ème suplément). Bulletin de la Société linnéenne de Bordeaux, 6(7-10): 27-43.

Jeanne, C., 1978. Carabiques de la Péninsule Ibérique (3ème suplément). Bulletin de la Société linnéenne de Bordeaux, 8: 21-47.

Jeanne, C. \& Zaballos, J. P., 1986. Catalogue des Coléoptères de la Péninsule Ibérique. Supplément au Bulletin de la Société linnéenne de Bordeaux. Bordeaux. $186 \mathrm{pp}$.

Juberthie, C., Delay, B. \& Bouillon, M., 1980. Extension du mileu souterrain en zone non-calcaire: description d'un nouveau milieu et de son peuplement par les coléoptères troglobies. Mémoires de Biospéologie, 7: 19-52.

López-Martínez, N., 1989. Tendencias en Paleobiogeografía. El futuro de la biogeografía del pasado. In: E. Aguirre coord. Nuevas tendencias. Vol. 10, Paleontología. C.S.I.C. Madrid: 271-296.

Mac Arthur, R. H. \& Wilson, E. O., 1967. The theory of island biogeography. Monographs on population biology, 1. Princeton University Press. Princeton. 203 pp.
Marshall, L. G., 1988. Land mammals and the Great American Interchange. American Scientist, 76: 380388.

NovoA, F., Mariño, J. \& Lombardero, J., 1996. Los Carabidae (Coleoptera) de los montes del Invernadeiro (NO Península Ibérica) y algunas consideraciones sobre la carabidofauna de las montañas orientales de Galicia. Boletín de la Real Sociedad española de Historia Natural (Sección Biológica), 92: 167-175.

NovoA, F., SÁez, M., EiroA, E. \& GonzÁlez, J., 1989. Los Carabidae (Coleoptera) de la Sierra de Ancares (Noroeste de la Península Ibérica). Boletín de la Real Sociedad española de Historia Natural (Sección Biológica), 84: 287-305.

Oosterbroek, P. \& Arntzen, J. W., 1992. Area-cladograms of Circum-Mediterranean taxa in relation to Mediterranean paleogeography. Journal of Biogeography, 19: 3-20.

ORTUÑo, V. M., 2002. Estado de conocimiento de los artrópodos de España. In: F. D. Pineda, J. M. de Miguel, M. A. Casado y J. Montalvo (eds.). La diversidad biológica de España. Pearson Educación. Madrid: 209-233.

Penev, L., Casale, A. \& Turin, H., 2003. Biogeography. In: H. Turin, L. Penev and A. Casale (eds.). The genus Carabus in Europe. A synthesis. Co-published by Pensoft Publishers, Sofia, and European Invertebrate Survey, Leiden: 327-425.

Rögl, F. \& Steininger, F. F., 1983. Vom Zerfall der Tethys zu Mediterran und Paratethys. Annalen des Naturhistorisches Museums in Wien, 85A: 135-1863.

Serrano, J., 2003. Catálogo de los Carabidae de la Península Ibérica e Islas Baleares. Monografías de la Sociedad Aragonesa de Entomología 9. Zaragoza. $129 \mathrm{pp}$.

TURIN, H., 2000. De nederlandse loopkevers. Verspreiding en Oecologie. (Coleoptera: Carabidae). Nederlandse Fauna 3. Nationaal Natuurhistorisch Museum Naturalis. Utrecht. 666 pp. + 16 láminas y CD-ROM.

Vigna Taglianti, A., Audisio, P. A., Belfiore, C., Biondi, M., Bologna, M. A., Carpaneto, G. M., De Biase, A., De Felici, S., Piatella, E., Racheli, T., Zapparoli, M. \& ZoIA, S., 1992. Riflessioni di gruppo sui corotipi fondomentali della fauna $\mathrm{W}$-paleartica ed i particolare italiana. Biogeographia, 16: 159-179.

Vigna Taglianti, A., Casale, A. \& Fattorini, S., 2002. I carabidi della Sicilia ed il loro significato biogeografico (Coleoptera, Carabidae). Bollettino della Accademia Gioenia di Scienze Naturali, 35(361): 435-464.

Zaballos, J. P. \& Jeanne, C., 1994. Nuevo catálogo de los carábidos (Coleoptera) de la Península Ibérica. Monografías de la Sociedad Entomológica Aragonesa, 1. Zaragoza. 159 pp. 




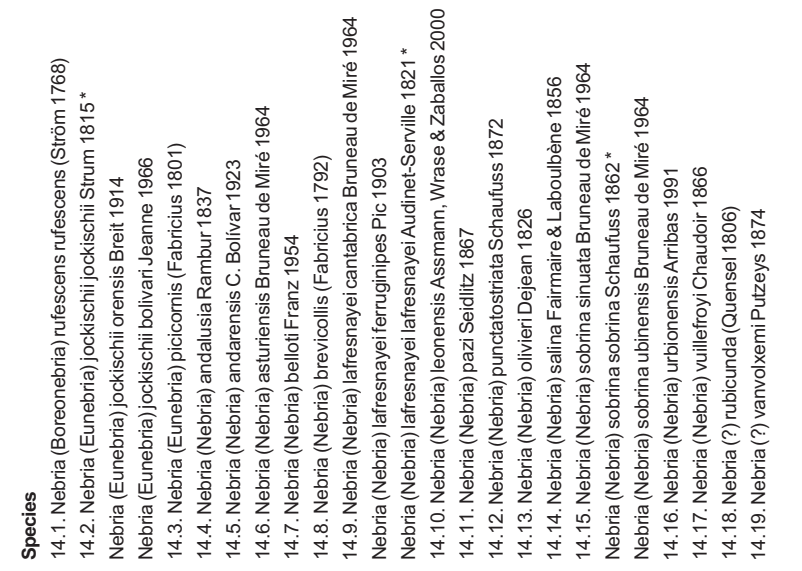

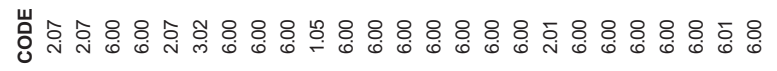

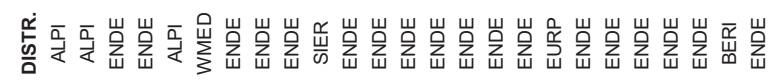

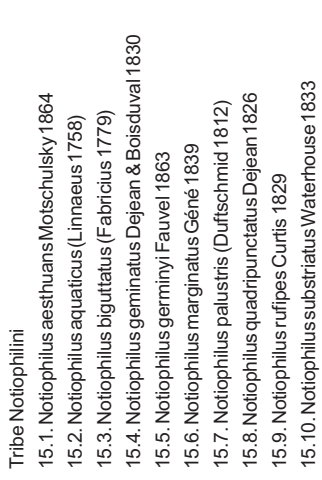

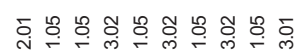

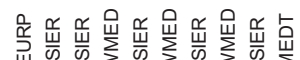

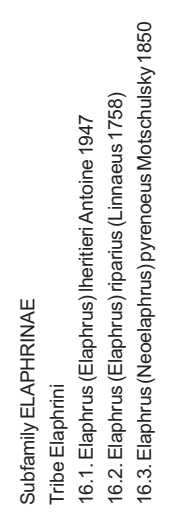

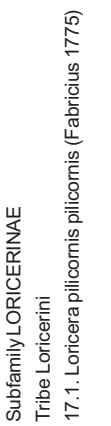

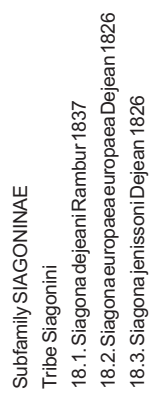

总哭:

巨్

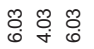

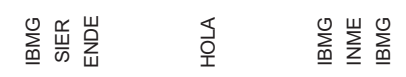

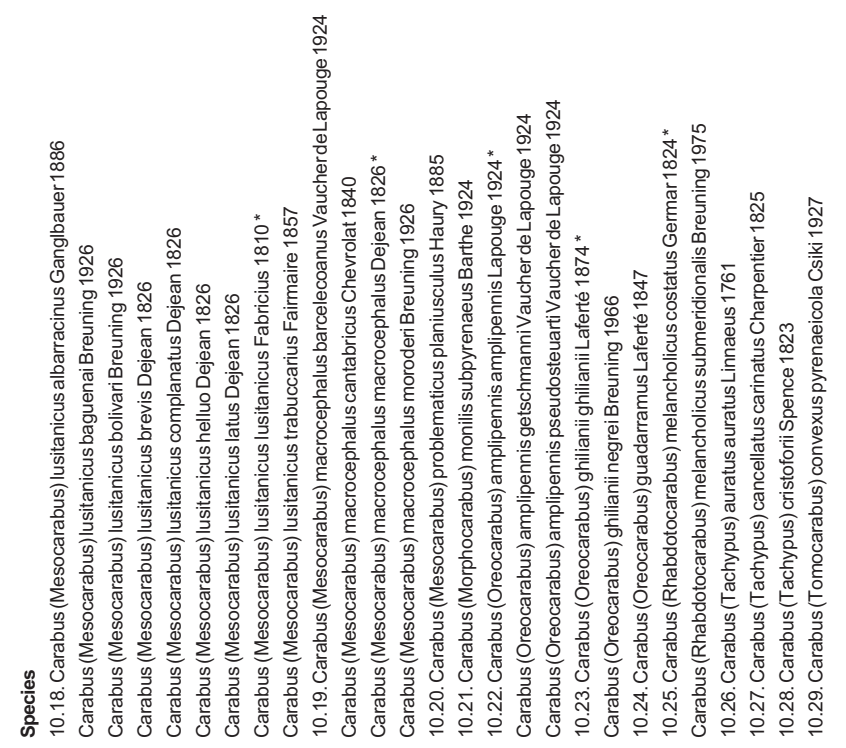

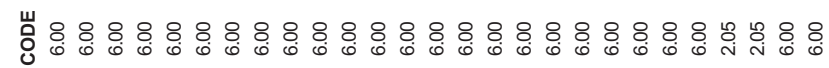

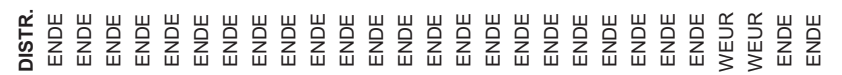

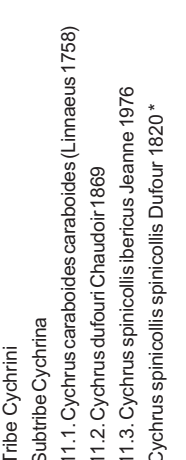

둥용용

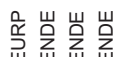

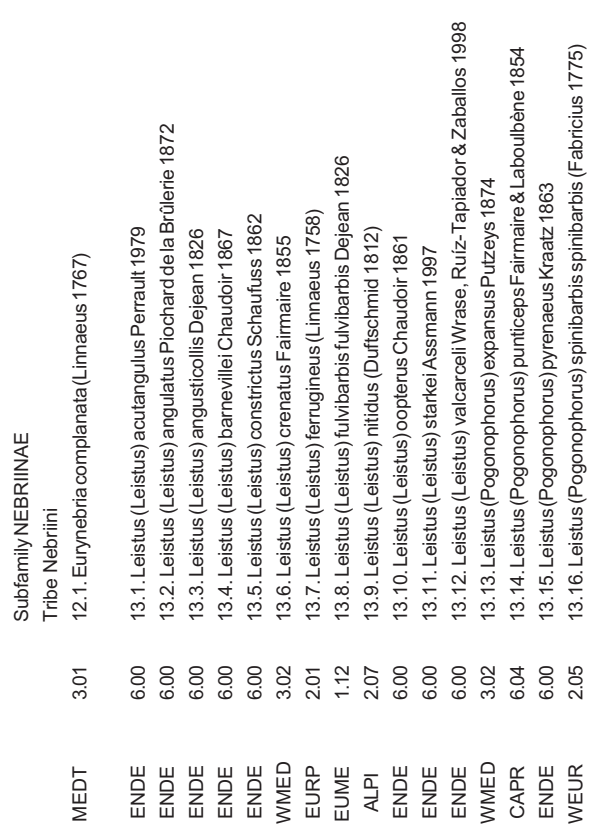

http://graellsia.revistas.csic.es 

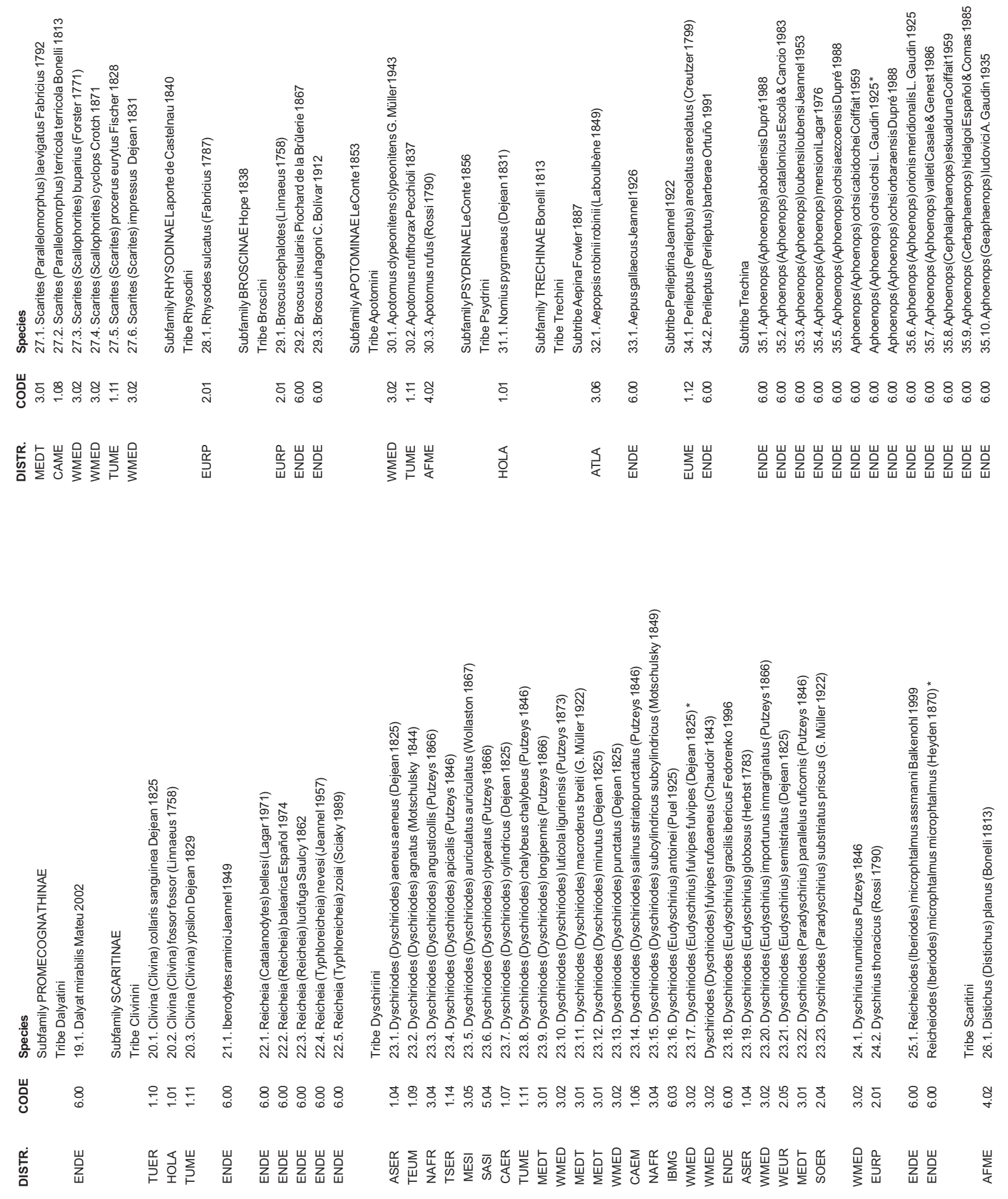


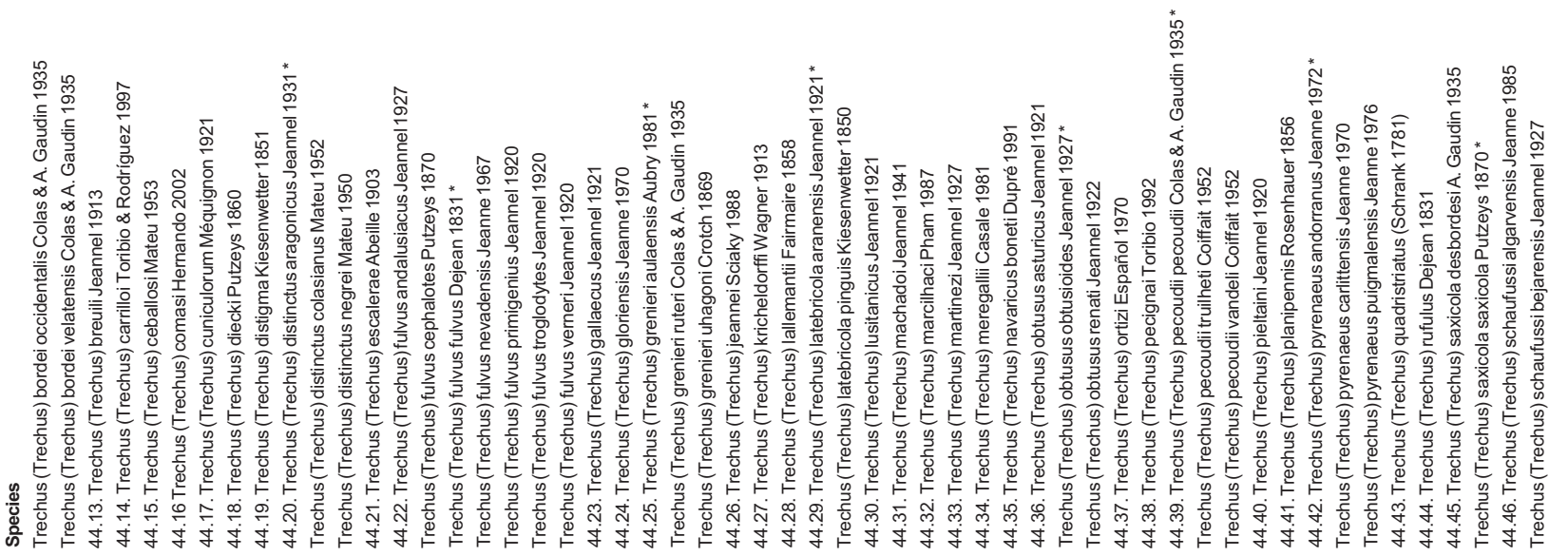

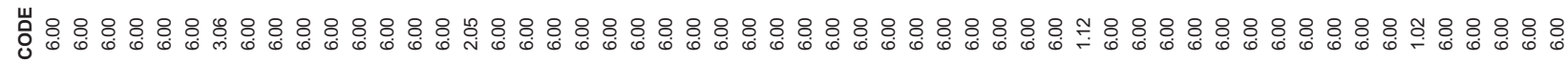

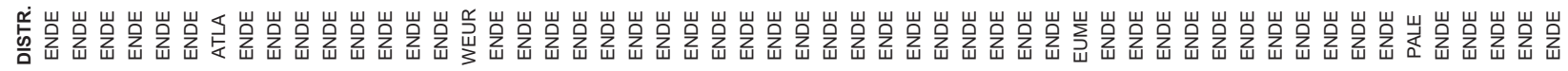

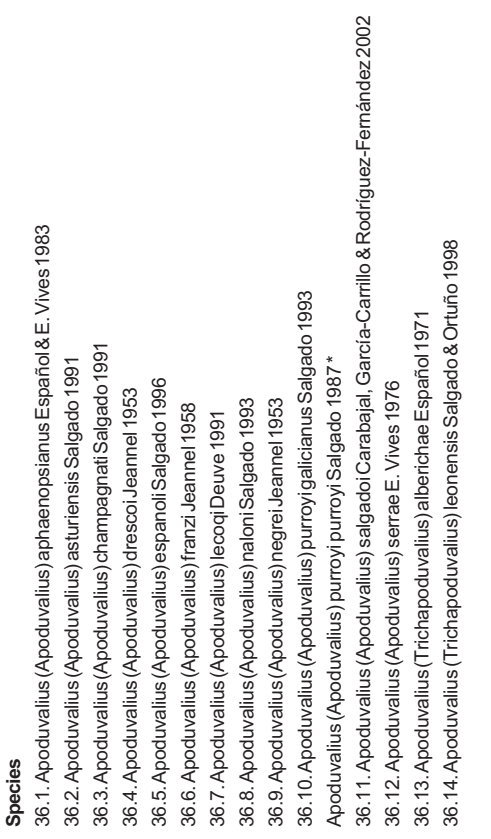

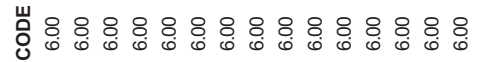

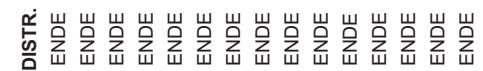
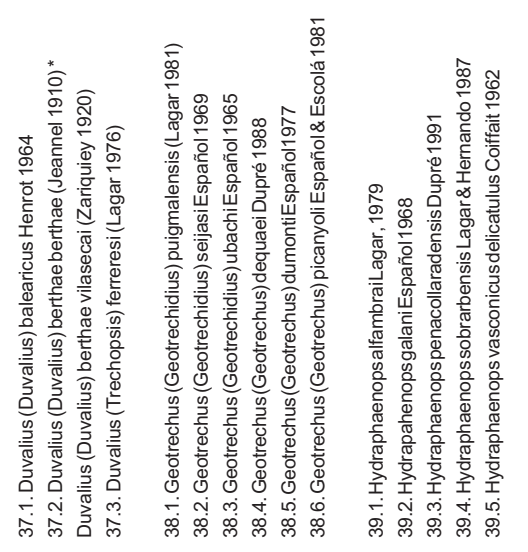

$8: 8: 8$

岁岁岂宸
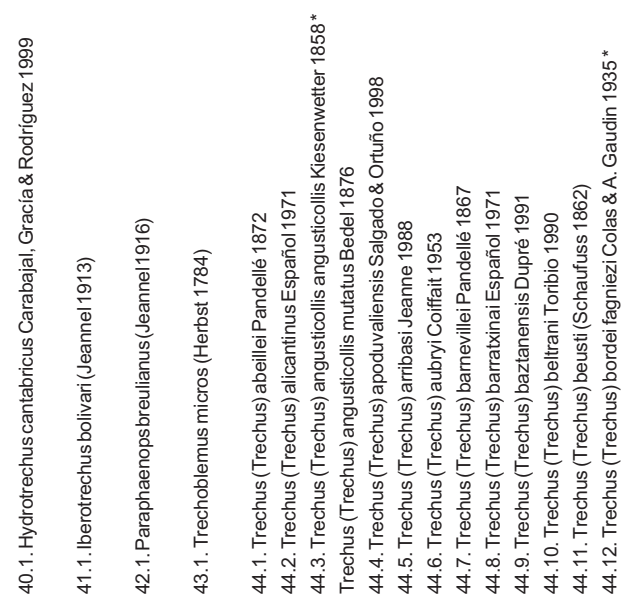

: : : : : : : :

: : $:$ : $:$ : : $\stackrel{8}{\circ}$

哭

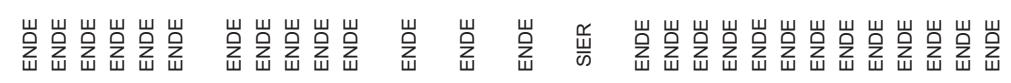



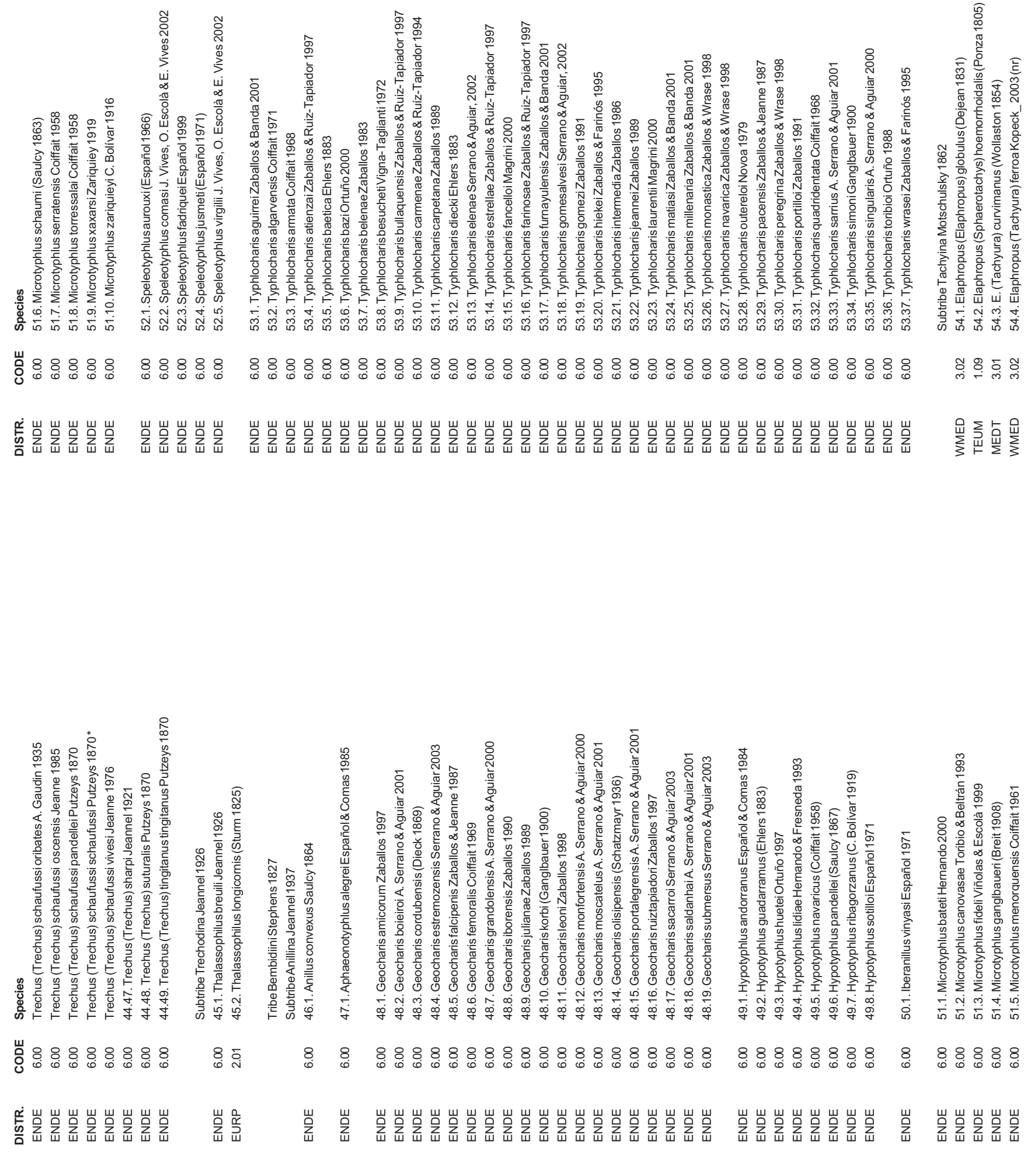


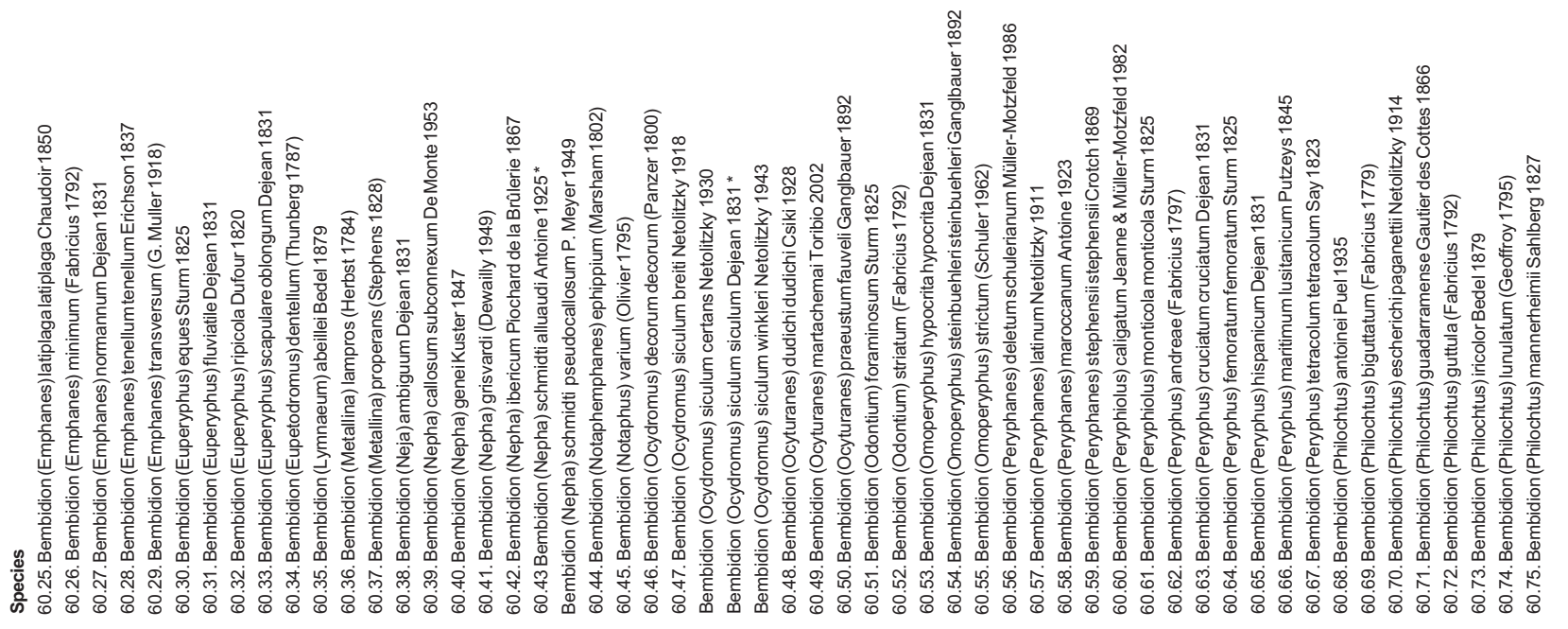

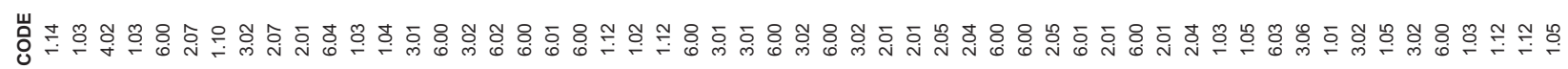

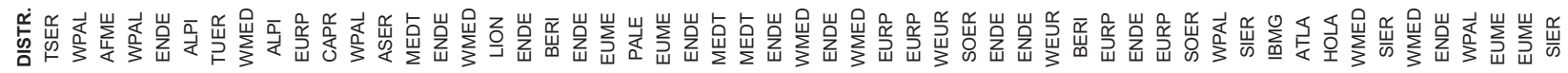

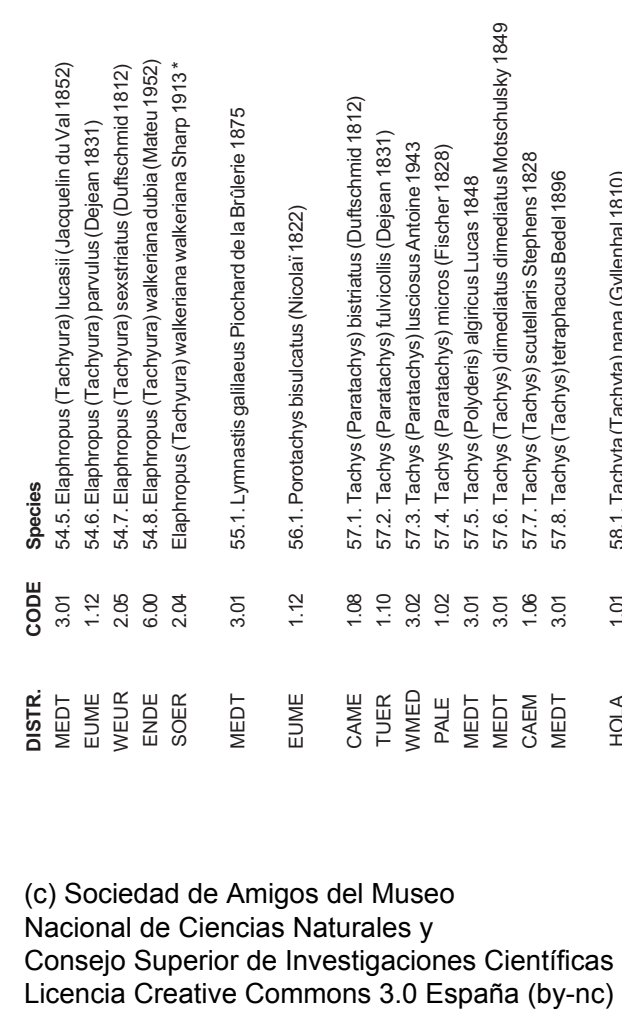

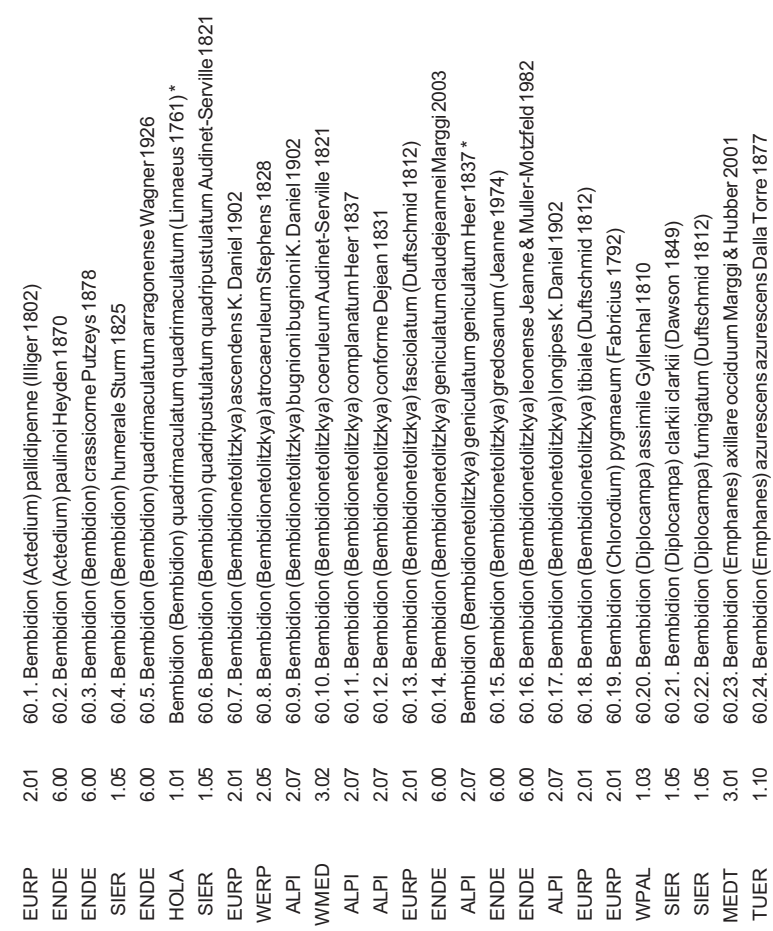

http://graellsia.revistas.csic.es 

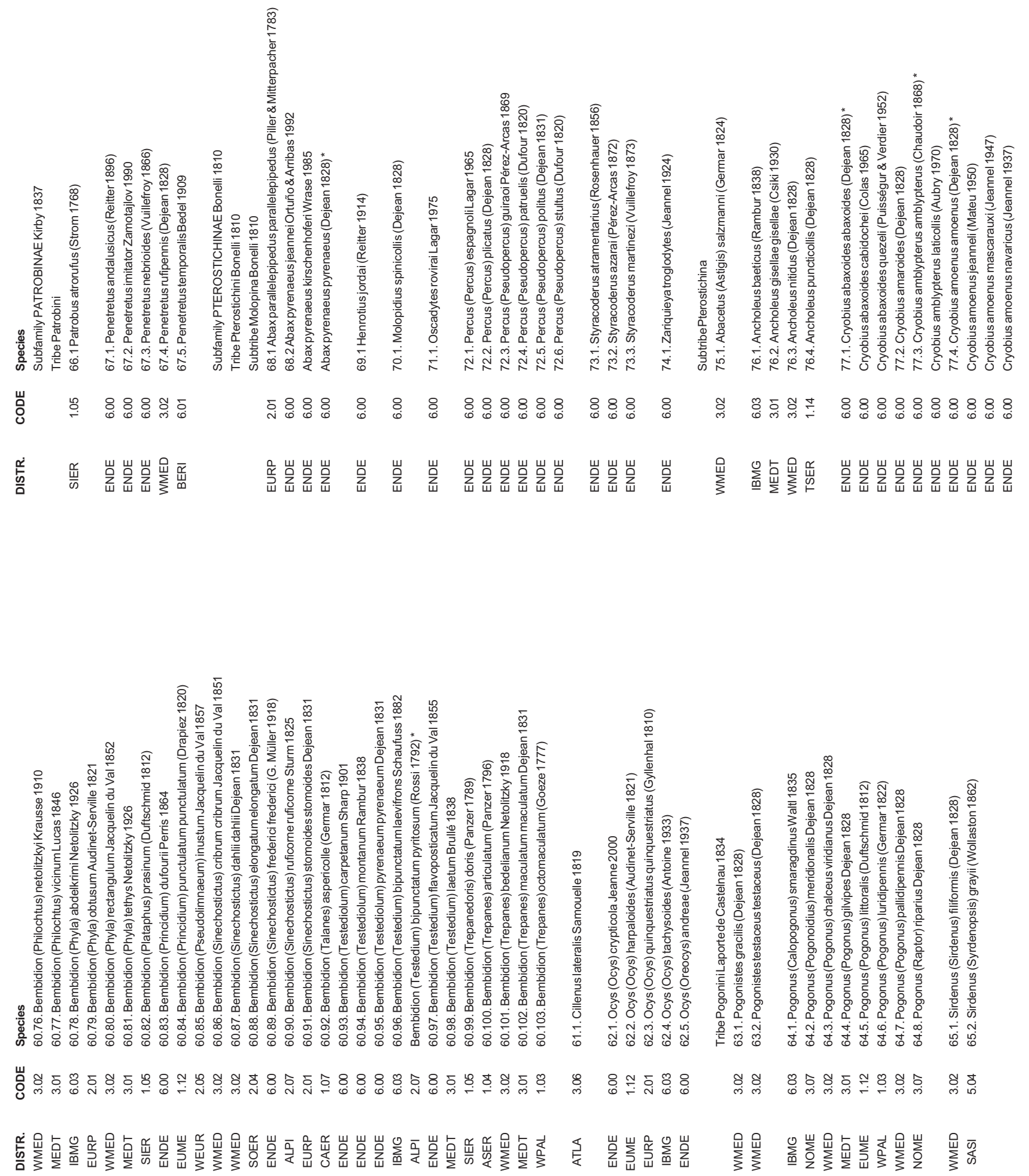


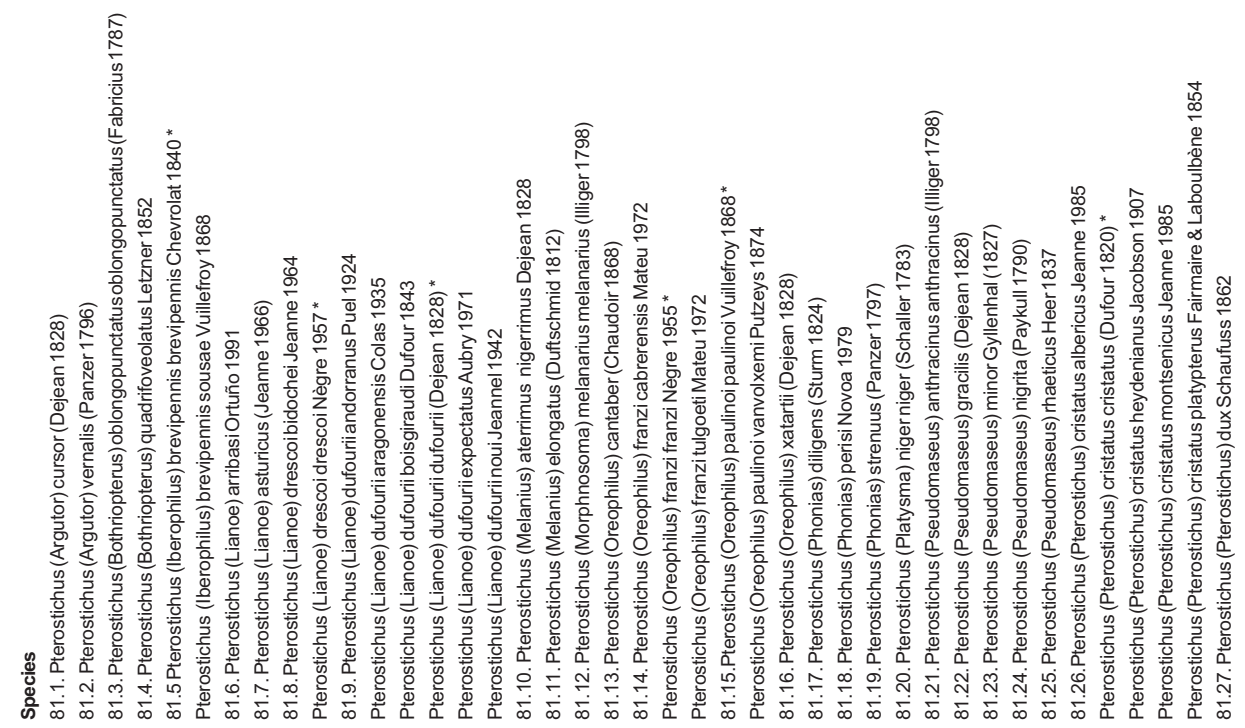

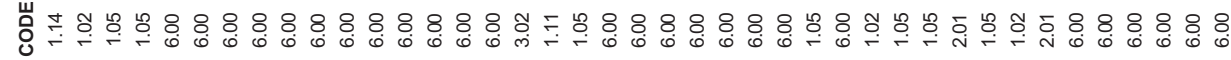

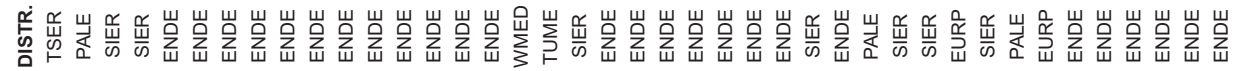

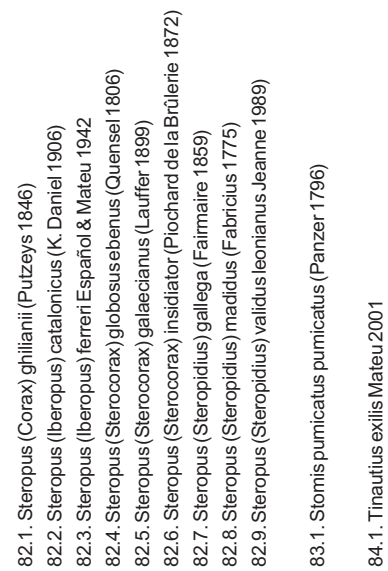

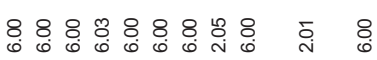

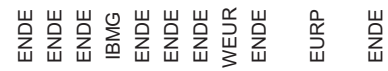

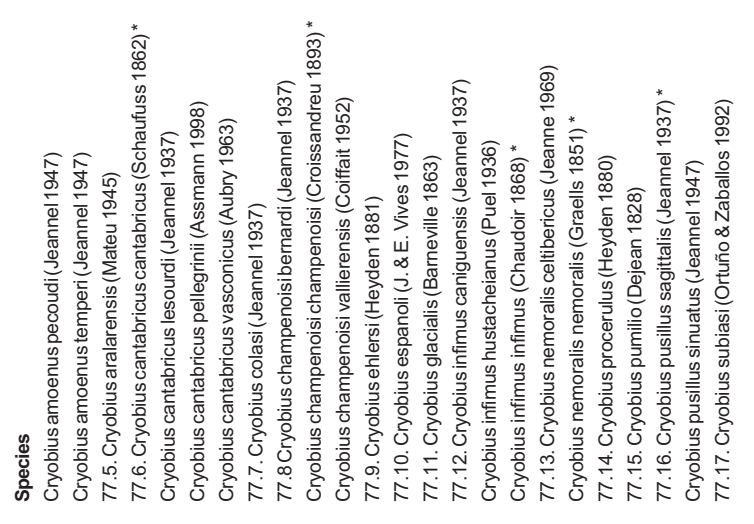

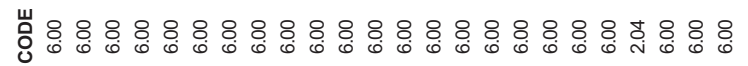

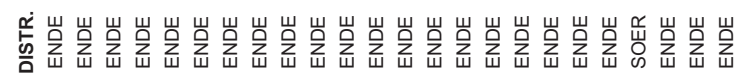

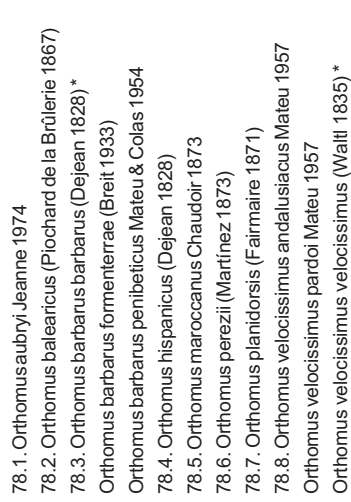

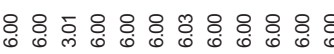

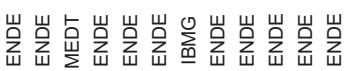

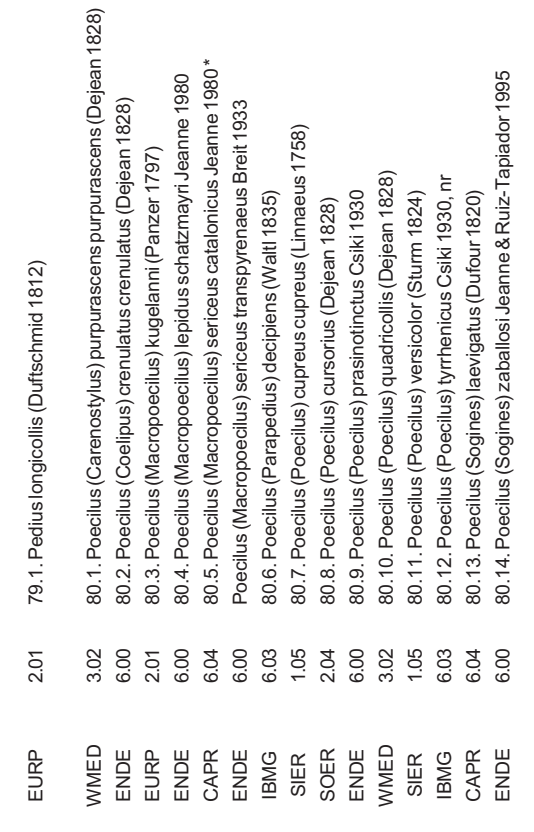

(c) Sociedad de Amigos del Museo 

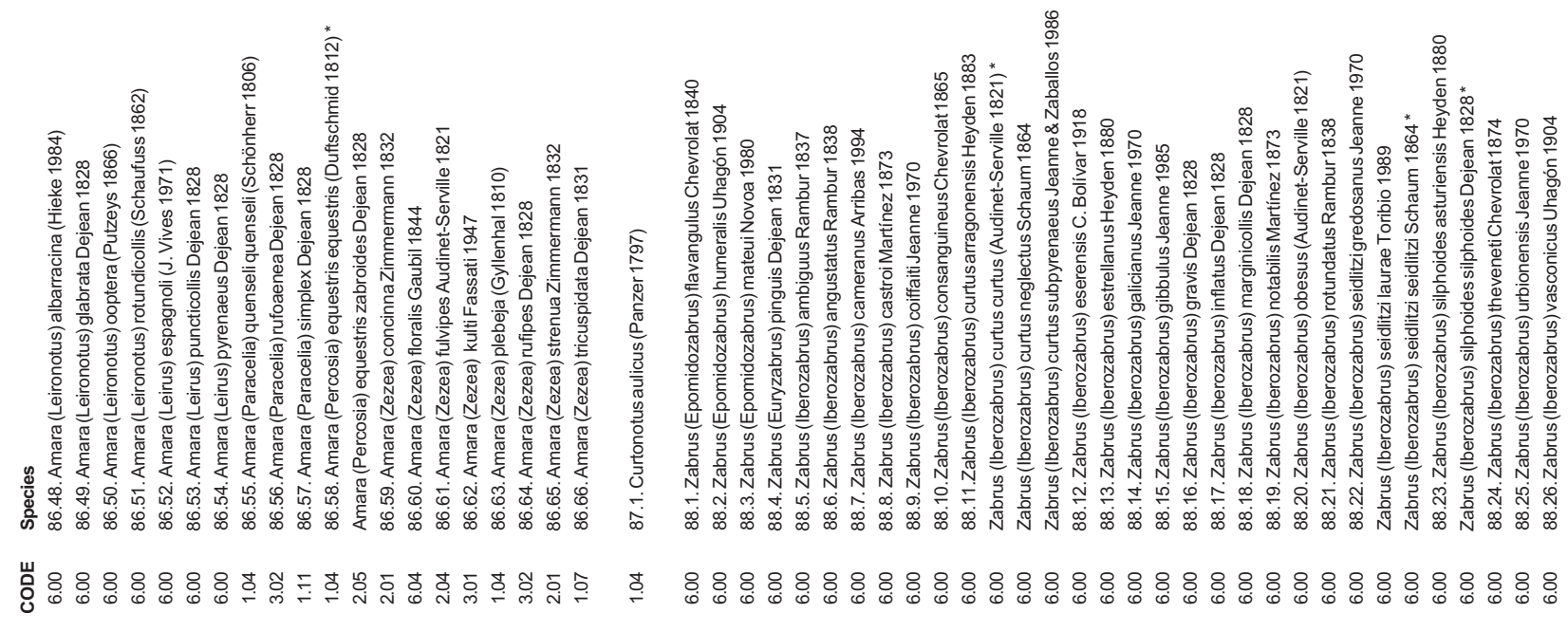

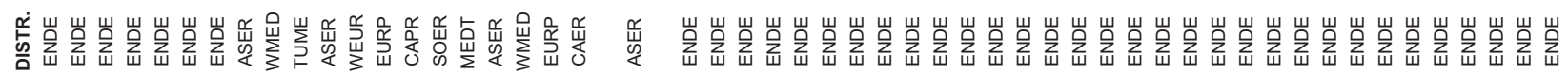

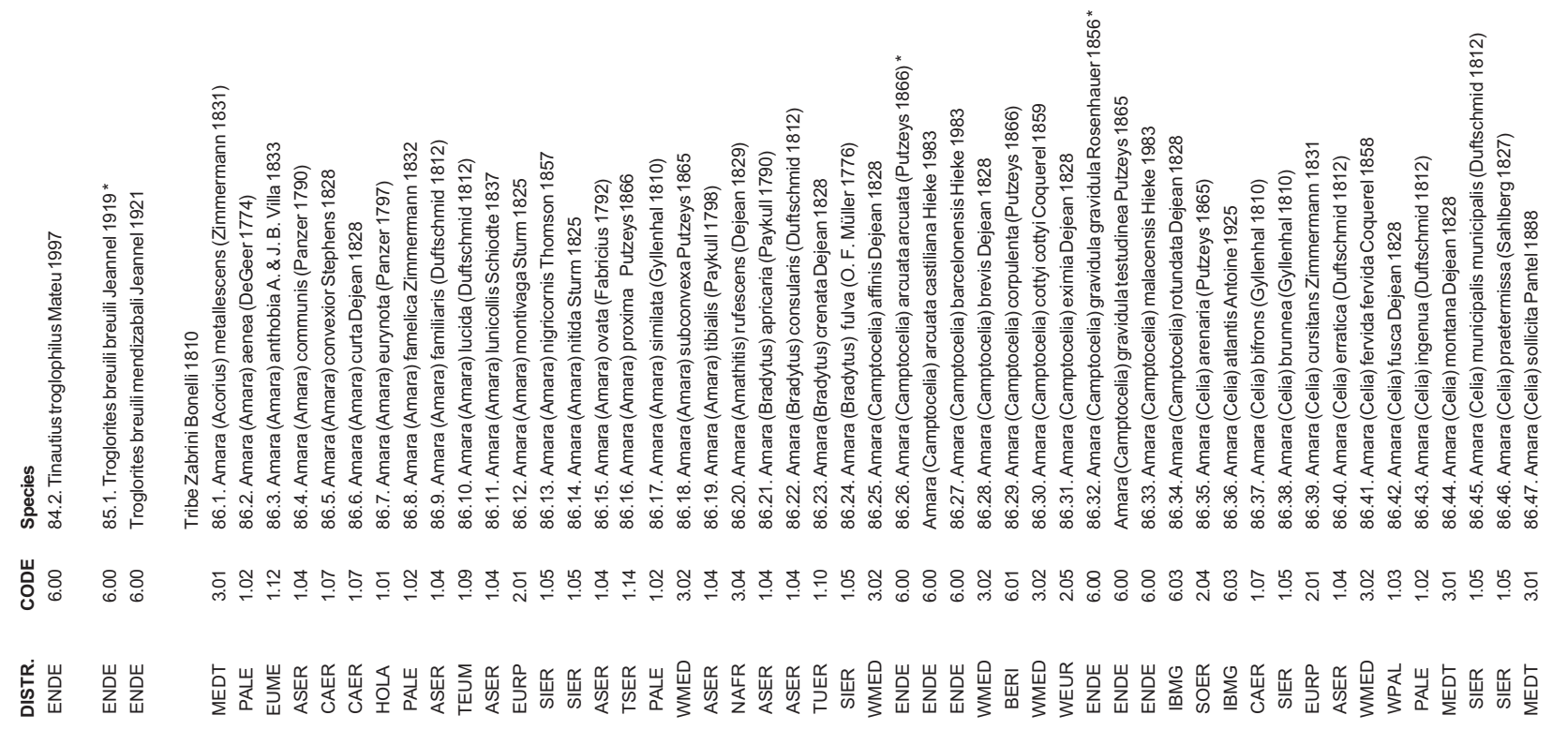




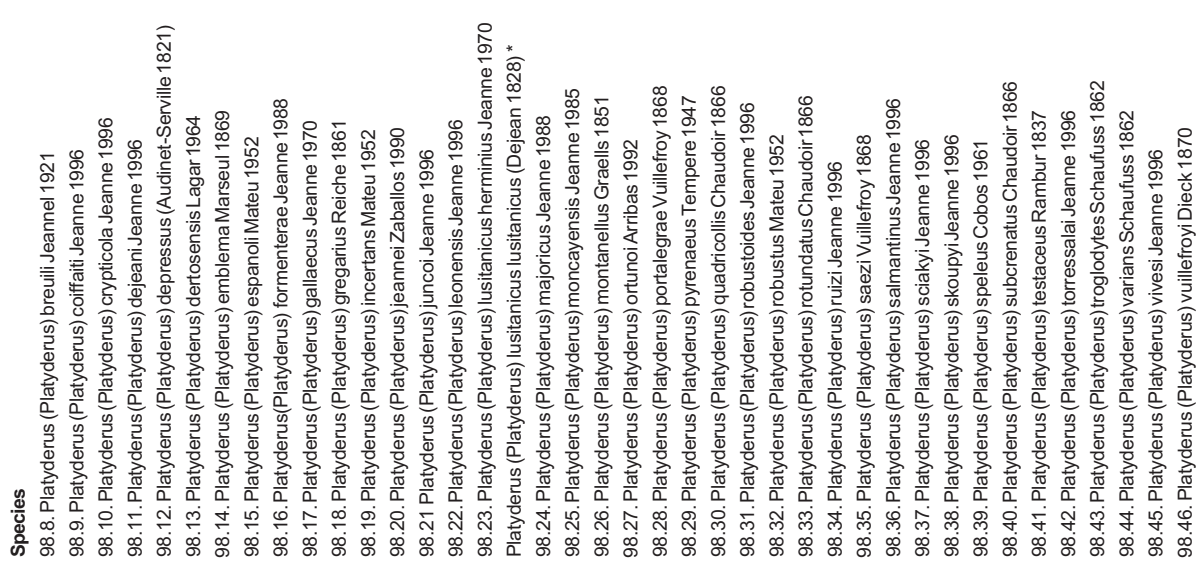

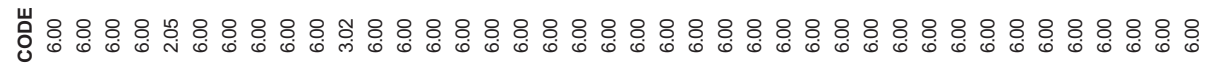

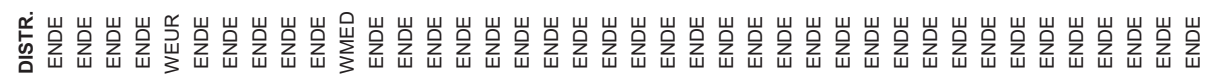

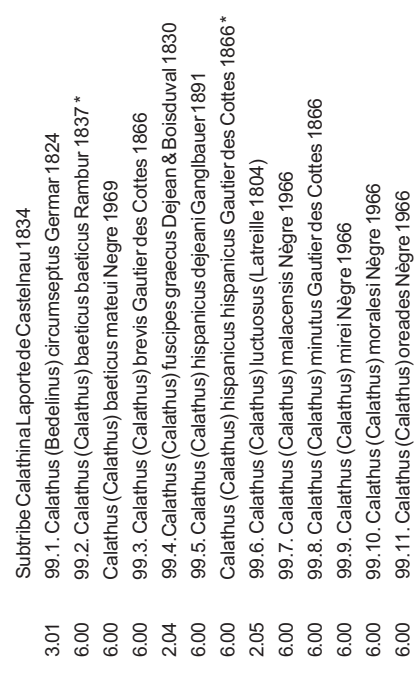

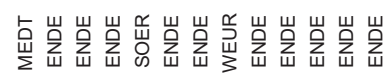

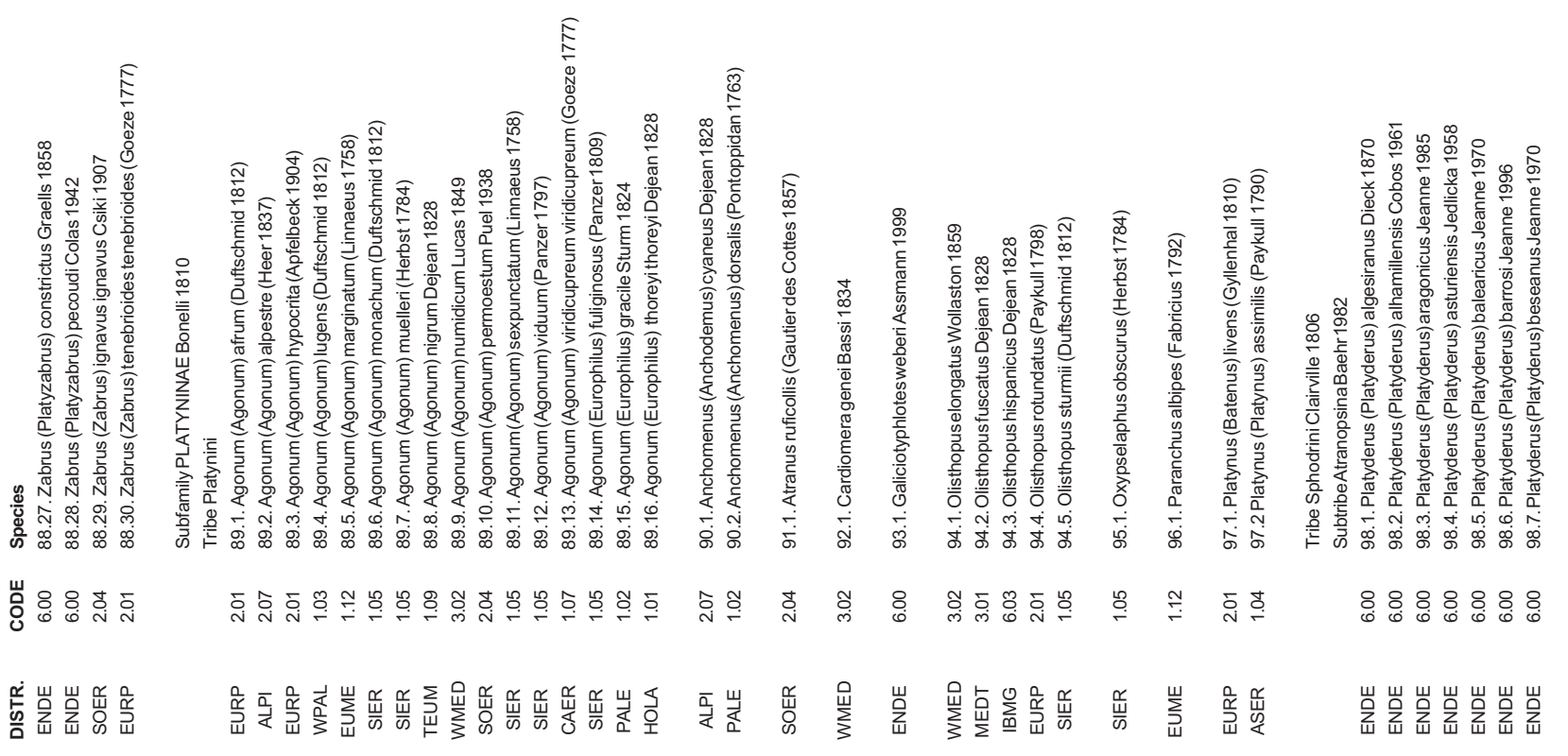



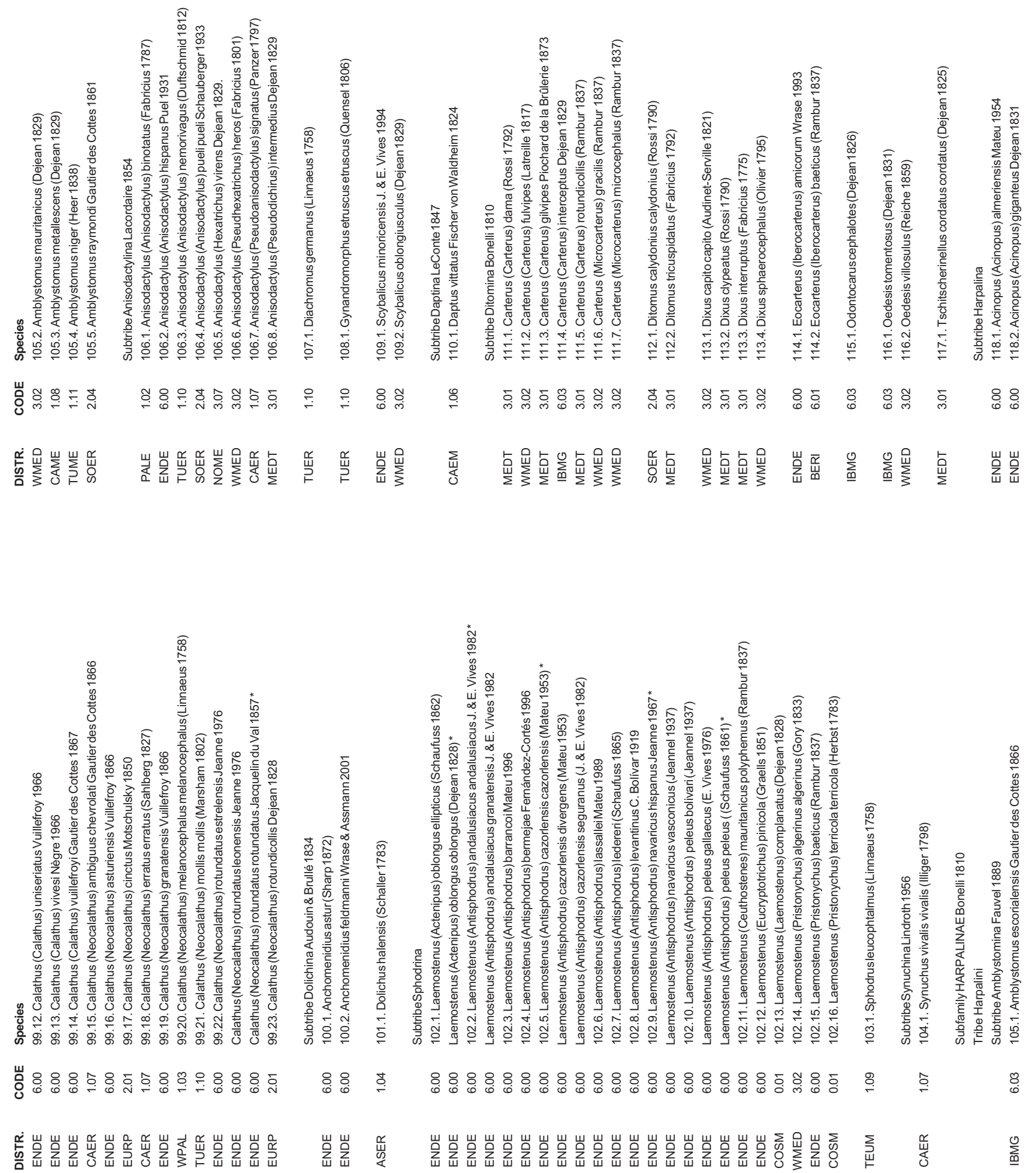

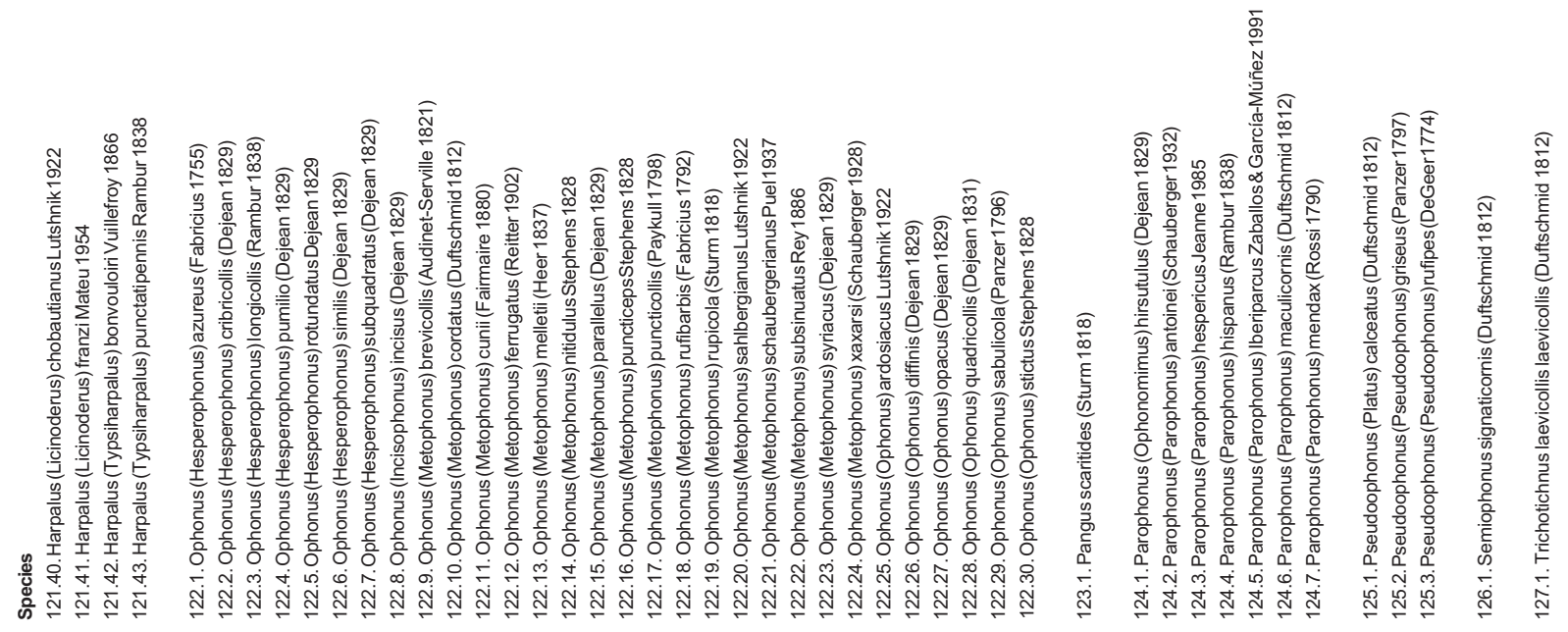

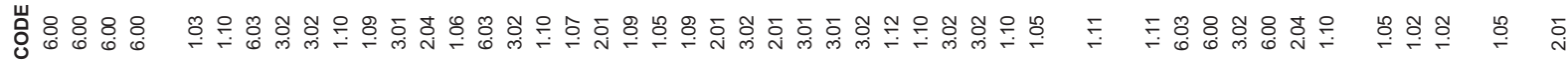

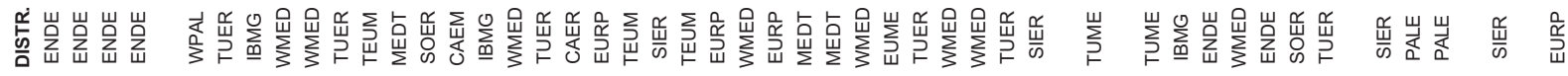

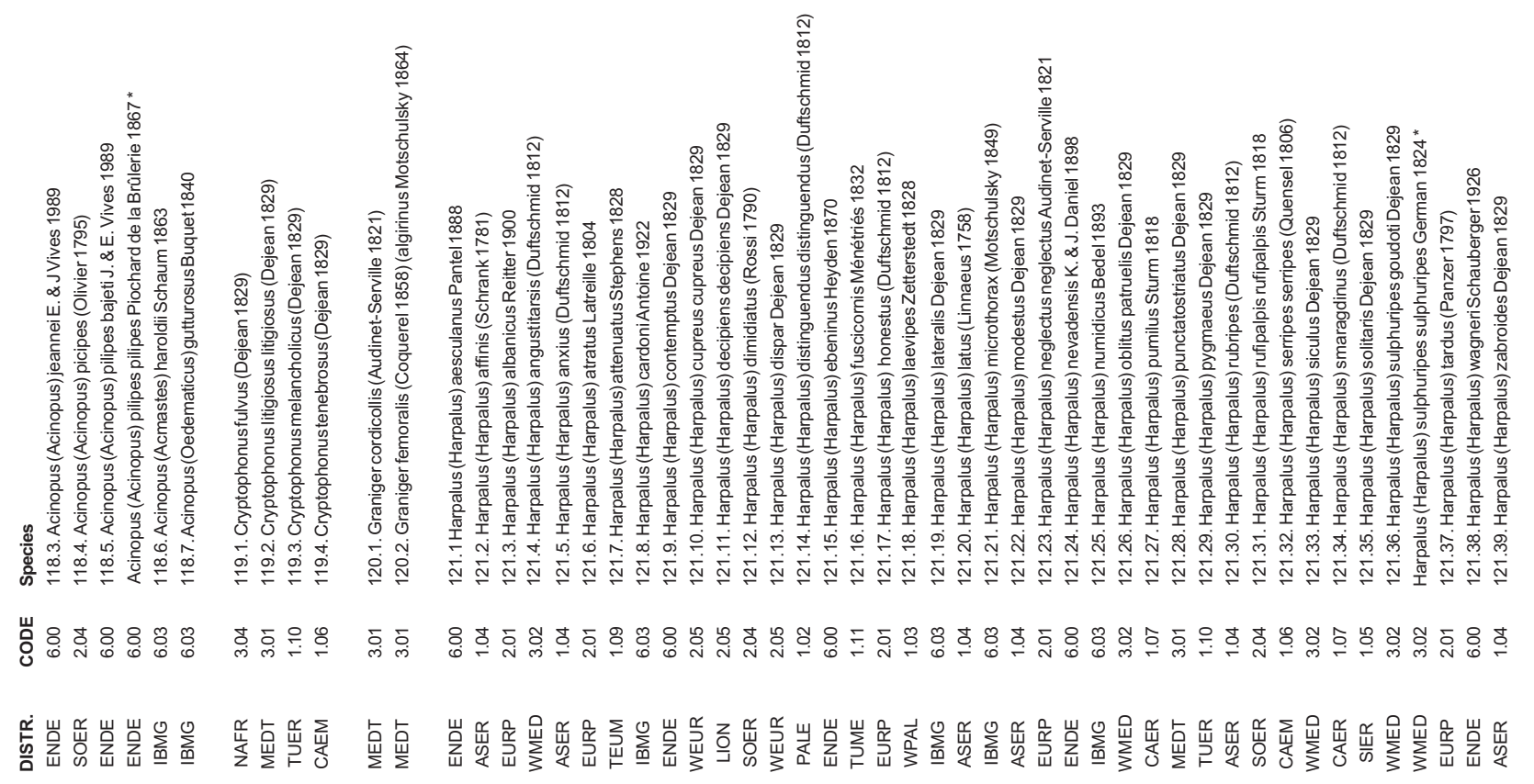

(c) Sociedad de Amigos del Museo

http://graellsia.revistas.csic.es 

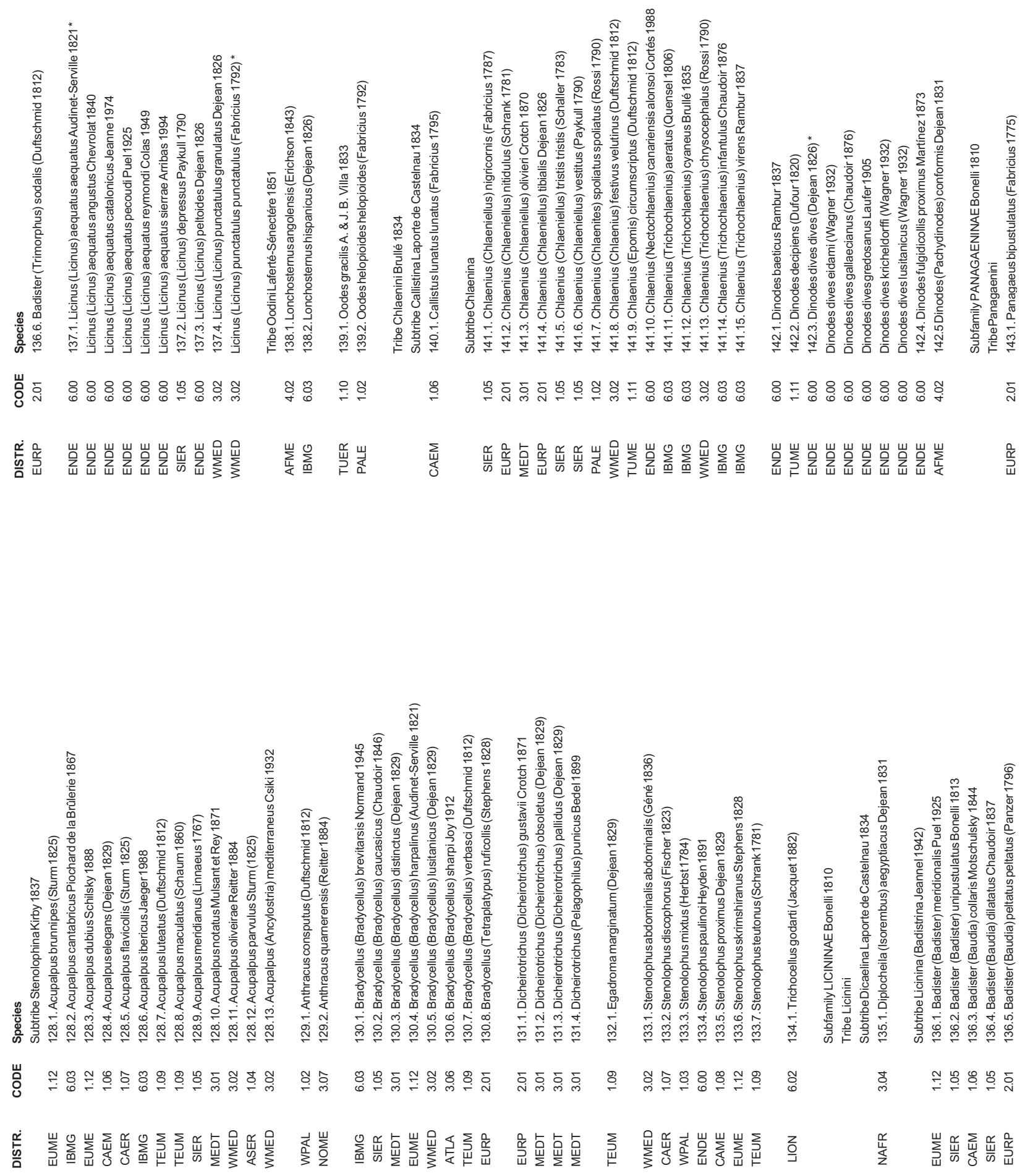

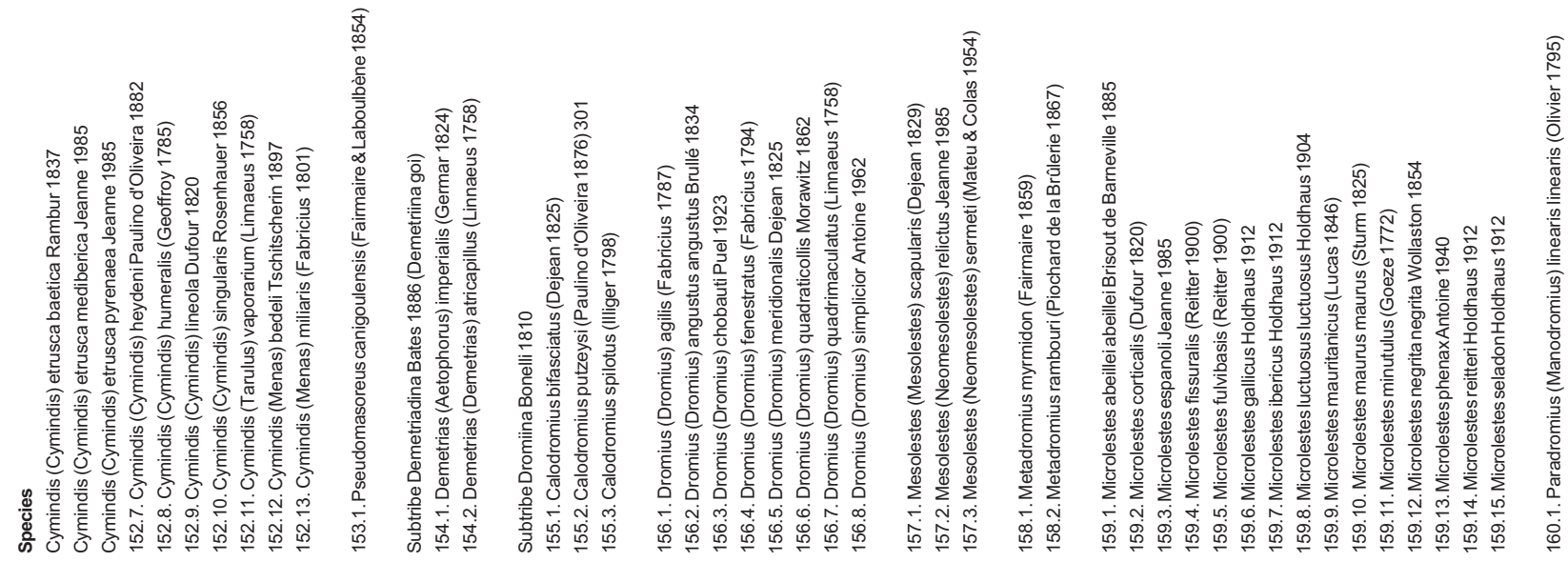

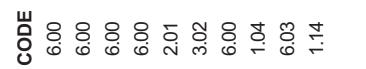

$\stackrel{\circ}{\stackrel{ }{ }}$

당 유ㅇㅛㅠ

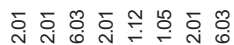

: 8

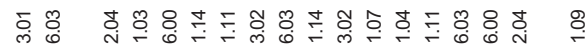

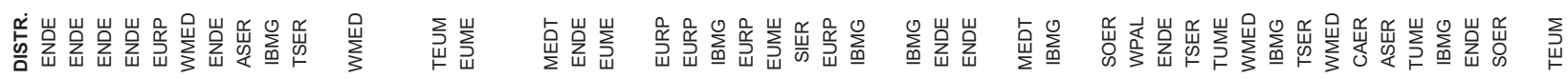

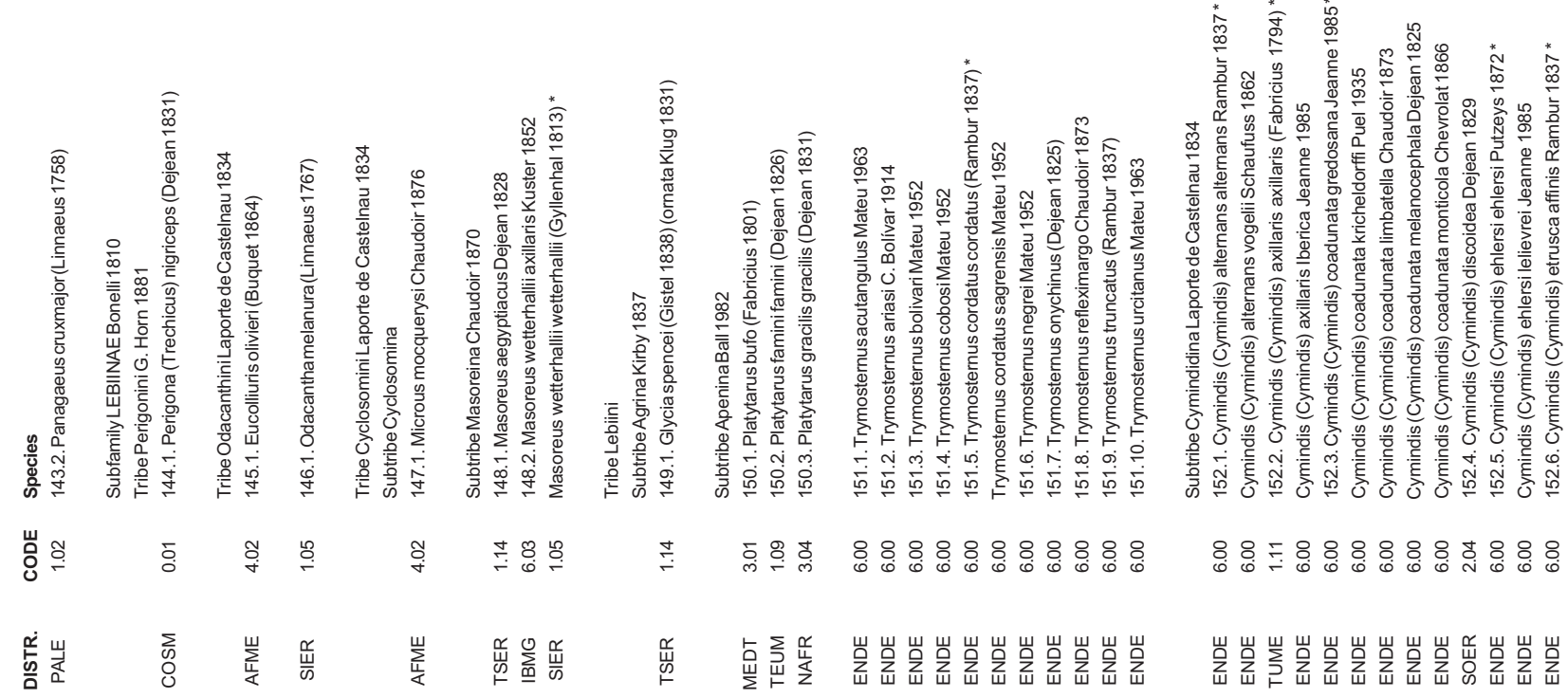




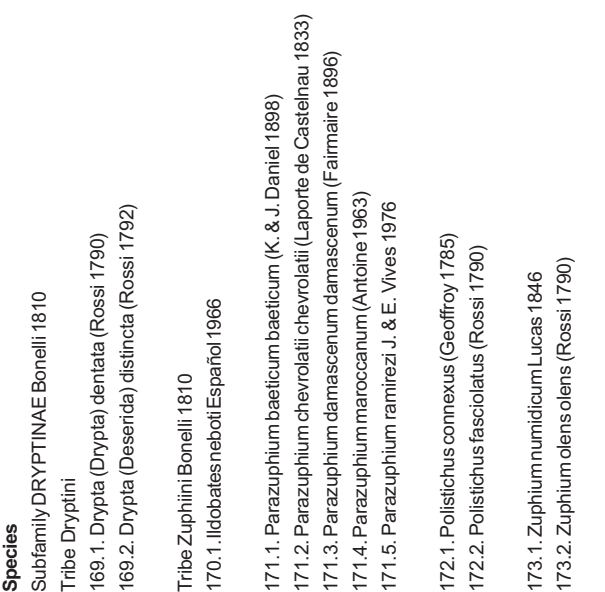

峞

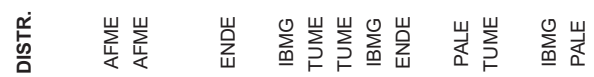

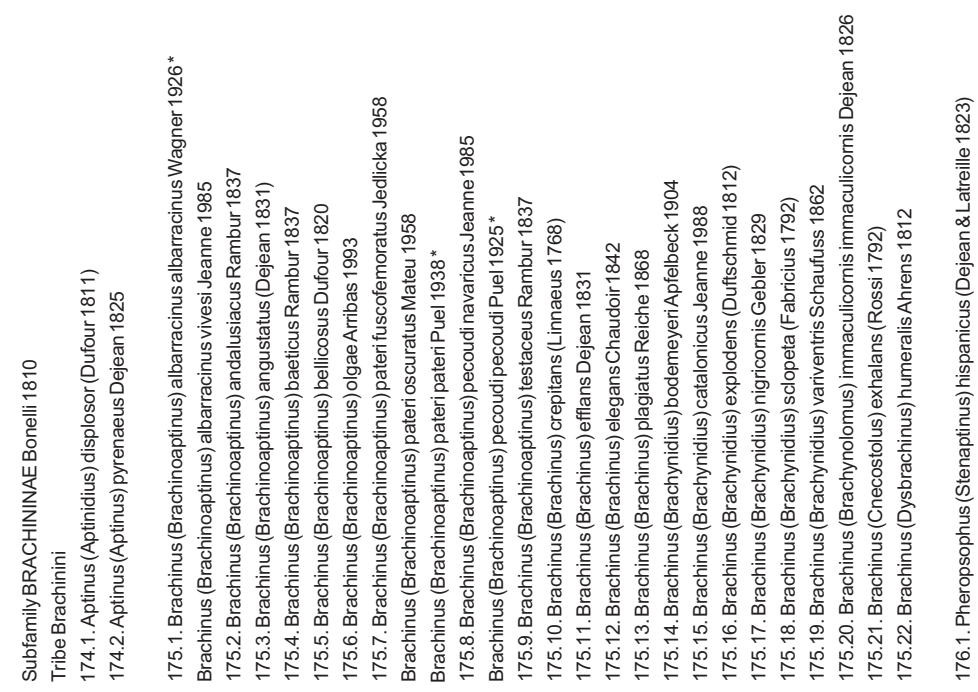

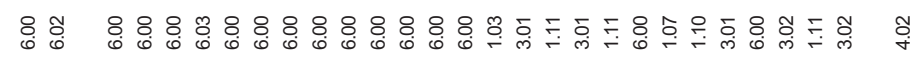

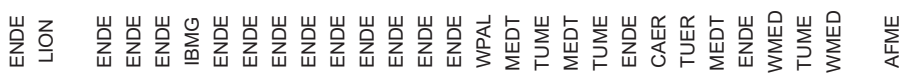

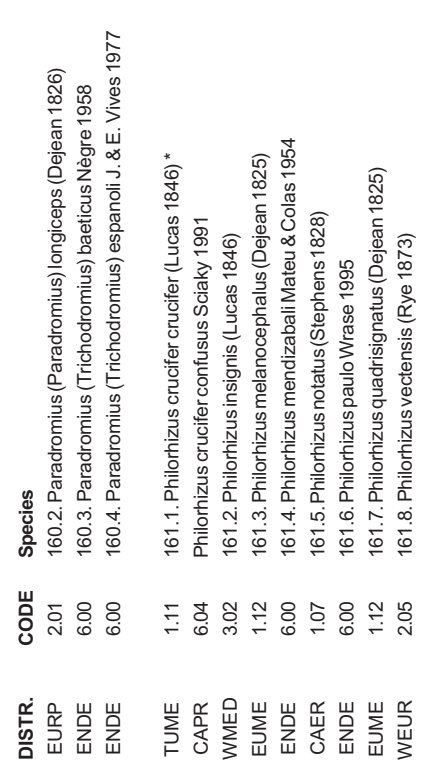

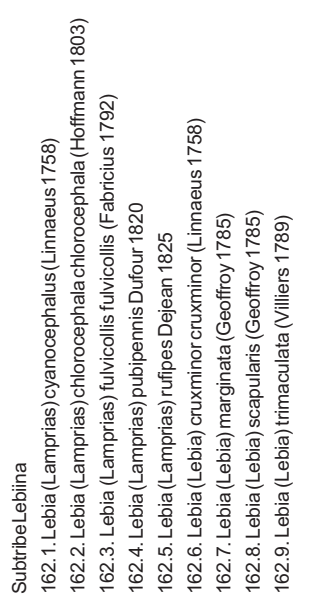

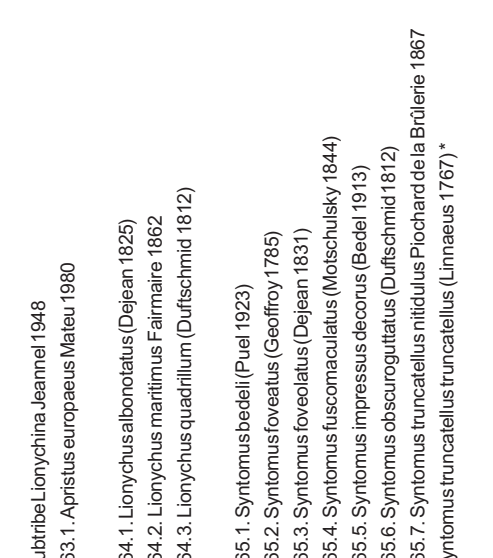

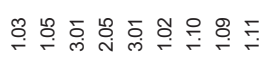

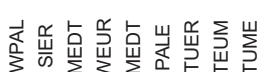

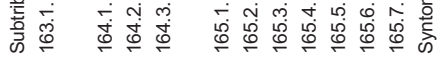

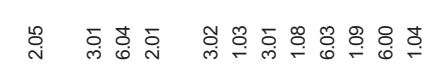

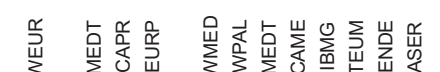

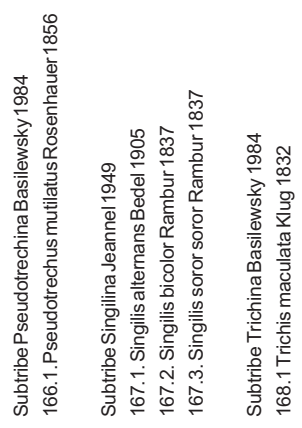

8

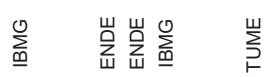

